OPEN ACCESS

Edited by: Aviv M. Weinstein, Ariel University, Israel

Reviewed by: Jacob Raber, Oregon Health \& Science University, United States

Edythe D. London, University of California, Los Angeles, United States

*Correspondence: Jee Hyun Kim drjeehyunkim@gmail.com

Specialty section: This article was submitted to Addictive Disorders, a section of the journal

Frontiers in Psychiatry

Received: 15 August 2019 Accepted: 07 November 2019 Published: 17 December 2019

Citation:

Guerin AA, Bonomo Y, Lawrence AJ, Baune BT, Nestler EJ, Rossell SL and Kim JH (2019) Cognition and Related Neural Findings on Methamphetamine Use Disorder: Insights and Treatment Implications From Schizophrenia Research. Front. Psychiatry 10:880. doi: 10.3389/fpsyt.2019.00880

\section{Cognition and Related Neural Findings on Methamphetamine Use Disorder: Insights and Treatment Implications From Schizophrenia Research}

\author{
Alexandre A. Guerin 1,2, Yvonne Bonomo ${ }^{3,4,5}$, Andrew John Lawrence ${ }^{1,2}$, \\ Bernhard Theodor Baune ${ }^{6}$, Eric J. Nestler ${ }^{7}$, Susan L. Rossell ${ }^{8,9}$ and Jee Hyun Kim 1,2,7* \\ ${ }^{1}$ Mental Health Theme, The Florey Institute of Neuroscience and Mental Health, Parkville, VIC, Australia, ${ }^{2}$ Florey Department \\ of Neuroscience and Mental Health, University of Melbourne, Parkville, VIC, Australia, ${ }^{3}$ Department of Addiction Medicine, St \\ Vincent's Hospital, Melbourne, VIC, Australia, ${ }^{4}$ Department of Medicine, University of Melbourne, Melbourne, VIC, Australia, \\ ${ }^{5}$ Women's Alcohol and Drug Service, Royal Women's Hospital, Melbourne, VIC, Australia, ${ }^{6}$ Department of Psychiatry, \\ University of Melbourne, Melbourne, VIC, Australia, ${ }^{7}$ Department of Neuroscience, Friedman Brain Institute, Icahn School \\ of Medicine at Mount Sinai, New York, NY, United States, ${ }^{8}$ Centre for Mental Health, Swinburne University of Technology, \\ Melbourne, VIC, Australia, ${ }^{9}$ Department of Psychiatry, St Vincent's Hospital, Melbourne, VIC, Australia
}

Despite the prevalence of methamphetamine (meth) use disorder, research on meth is disproportionately scarce compared to research on other illicit drugs. Existing evidence highlights cognitive deficits as an impediment against daily function and treatment of chronic meth use. Similar deficits are also observed in schizophrenia, and this review therefore draws on schizophrenia research by examining similarities and differences between the two disorders on cognition and related neural findings. While meth use disorder and schizophrenia are two distinct disorders, they are highly co-morbid and share impairments in similar cognitive domains and altered brain structure/function. This narrative review specifically identifies overlapping features such as deficits in learning and memory, social cognition, working memory and inhibitory/impulse control. We report that while working memory deficits are a core feature of schizophrenia, such deficits are inconsistently observed following chronic meth use. Similar structural and functional abnormalities are also observed in cortical and limbic regions between the two disorders, except for cingulate activity where differences are observed. There is growing evidence that targeting cognitive symptoms may improve functional outcome in schizophrenia, with evidence of normalized abnormal brain activity in regions associated with cognition. Considering the overlap between meth use disorder and schizophrenia, targeting cognitive symptoms in people with meth use disorder may also improve treatment outcome and daily function.

Keywords: methamphetamine use disorder, schizophrenia, cognition, memory, brain, MRI 


\section{INTRODUCTION}

Methamphetamine (meth) use disorder is defined by the Diagnostic and Statistical Manual of Mental Disorders 5th edition (DSM-5) as a substance use disorder characterized by compulsive meth-taking and -seeking despite serious negative consequences (1). Amphetamines are the second most used illicit drug in the world, second only to cannabis (2). Meth represents the majority of illicitly used amphetamines and is an urgent global health threat, with a rapidly increasing market (3). The Substance Abuse and Mental Health Services Administration estimated that close to 13 million people in the United States used meth in their lifetime ( $4 \%$ of the total population), with 569,000 people using meth in the past month (4). There is no government-approved medication to treat meth use disorder, and existing psychological interventions need much improvement in efficacy (5).

Despite the prevalence and associated harm, PubMed indicates that research on meth is disproportionately low compared to other substance use disorders (6) and other mental disorders. We thus propose to harness existing research in schizophrenia to provide much needed insight into meth use disorder to improve and innovate its therapeutics considering the evidence for their shared psychotic symptoms and genetic vulnerability (7-9). Schizophrenia is a chronic neuropsychiatric disorder characterized by disturbances in thought, perception, and behavior (1), and it is an extensively researched field with PubMed publications per year almost doubling all of illicit substance publications per year and more than ten times the number of publications on meth (Figure 1). Other than its wealth of existing data, schizophrenia is one of the best fields to leverage to understand meth use disorder because it is highly co-morbid with meth use (10). Meth is amongst the most used illicit substance in people with schizophrenia (11). Importantly, chronic meth use might promote the development of schizophrenia in at-risk individuals $(12,13)$, and a major animal model to capture some

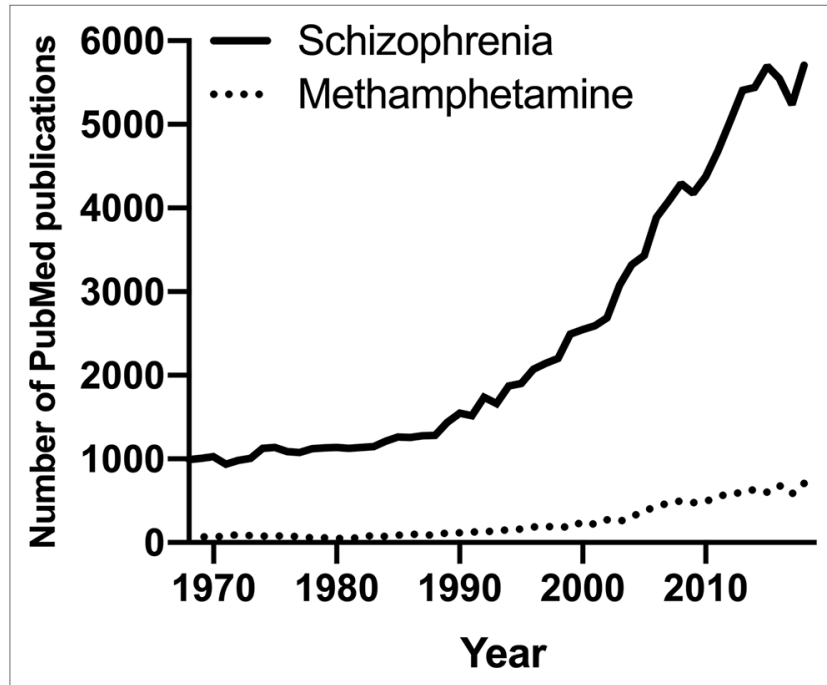

FIGURE 1| The number of PubMed publications in the last 50 years on schizophrenia or methamphetamine. of schizophrenia-like psychotic symptoms relies on chronic meth exposure (14). For example, impairment in prepulse inhibition, a measurement of sensorimotor gating deficits often observed in people with schizophrenia (15), can be elicited following chronic meth exposure in rodents (16-19). To the best of our knowledge, no study has assessed sensorimotor gating impairment in people with meth use disorder, but rodent evidence suggests that chronic meth exposure in early life and adolescence may lead to long-lasting deficits in prepulse inhibition in adulthood in mice $(20,21)$.

Taken together, cognitive deficits and their associated neural dysfunction characterize both disorders (22-29). However, they have never been explicitly compared. The shared cognitive deficits are important to understand considering that many schizophrenia patients use psychostimulants as self-medication to reduce positive and negative symptoms, and improve mood states (30). Such efforts in turn may potentiate or exacerbate cognitive symptoms. Also, cognitive deficits are associated with poorer functional outcome in both disorders (31-33), hence existing effective therapies targeting cognitive deficits in schizophrenia may provide treatment avenues for similar deficits in meth use disorder.

The aim of this review is first to compare and contrast the cognitive impairments and related brain structure/activity between meth use disorder and schizophrenia. While many of the impairments are similar between the two, the associated neural changes can be different, which is important to understand the potential nuances in shared factors between the two disorders. We will then discuss approaches to treat cognitive symptoms in both disorders, with a focus on cognitive remediation therapy (CRT). The current review exclusively discusses studies in people with a DSM-IV or DSM-5 diagnosis of meth use disorder/dependence rather than to broadly include studies examining acute or casual meth users. This is to limit the substantial variability observed in findings due to large differences in meth intake between casual vs dependent users. Acute meth use and associated meth-induced psychosis-related cognitive deficits will not be discussed. Notably, there are limited studies that have directly compared people with meth use disorder and schizophrenia. We thus examined characteristics that were explicitly investigated in people with meth use disorder (Table 1) and then compared them against independent findings on schizophrenia. Where possible, studies that have directly compared the two disorders were highlighted.

\section{COGNITIVE DEFICITS AND RELATED BRAIN DYSFUNCTION}

Meth specifically acts on dopamine release by disrupting intravesicular $\mathrm{pH}$ and reversing transport of dopamine via plasma membrane transporters, which impairs the uptake of dopamine and its concentration within synaptic vesicles. The result is higher cytosolic concentrations of dopamine in nerve terminals, which leads to excess dopamine concentration in the synaptic cleft (71-73). This likely leads to lasting neuroadaptations (74) to affect cognition. Subcortical hyperdopaminergia and prefrontal hypodopaminergia is hypothesized to be part of the 
TABLE 1 | Summary of studies that have investigated cognitive deficits in meth use disorder, ordered in ascending order of shortest abstinence length reported in the sample. Percentage of female participant is specified if reported.

\begin{tabular}{|c|c|c|c|c|c|c|c|c|c|c|}
\hline \multirow[t]{2}{*}{ Study } & \multirow[t]{2}{*}{ Sample } & \multirow[t]{2}{*}{ n (\% females) } & \multicolumn{2}{|c|}{ Learning and Memory } & \multicolumn{2}{|c|}{ Social Cognition } & \multicolumn{2}{|c|}{ Working Memory } & \multicolumn{2}{|c|}{ Inhibition \& Impulsive Control } \\
\hline & & & $\begin{array}{l}\text { Types } \\
\text { (measures) }\end{array}$ & $\begin{array}{l}\text { Impaired in } \\
\text { meth? }\end{array}$ & $\begin{array}{l}\text { Types } \\
\text { (measures) }\end{array}$ & $\begin{array}{l}\text { Impaired in } \\
\text { meth? }\end{array}$ & $\begin{array}{l}\text { Types } \\
\text { (measures) }\end{array}$ & $\begin{array}{l}\text { Impaired in } \\
\text { meth? }\end{array}$ & $\begin{array}{l}\text { Types } \\
\text { (measures) }\end{array}$ & $\begin{array}{l}\text { Impaired in } \\
\text { meth? }\end{array}$ \\
\hline \multirow[t]{2}{*}{ Dean et al. (34) } & Healthy & $17(53 \%)$ & & & & & $\begin{array}{l}\text { Verbal; Visual } \\
\text { (LNS; SCAP) }\end{array}$ & No & $\begin{array}{l}\text { Inhibition } \\
\text { (Stroop color- } \\
\text { word; CPT; } \\
\text { ANT) }\end{array}$ & Yes \\
\hline & $\begin{array}{l}\text { Chronic meth } \\
\text { users (current) }\end{array}$ & $24(50 \%)$ & & & & & & & & \\
\hline \multirow[t]{2}{*}{ Lyoo et al. (35) } & Healthy & $120(20 \%)$ & & & & & & & $\begin{array}{l}\text { Inhibition (Stroop } \\
\text { color-word) }\end{array}$ & Yes \\
\hline & $\begin{array}{l}\text { Chronic meth } \\
\text { users (current) }\end{array}$ & $106(21 \%)$ & & & & & & & & \\
\hline \multirow[t]{2}{*}{ Mahoney et al. (36) } & Healthy & $31(45 \%)$ & & & & & & & Impulsivity (BIS) & Yes \\
\hline & $\begin{array}{l}\text { Chronic meth } \\
\text { users (current) }\end{array}$ & $31(29 \%)$ & & & & & & & & \\
\hline \multirow[t]{2}{*}{ Kim et al. (37) } & Healthy & $53(23 \%)$ & & & & & & & $\begin{array}{l}\text { Inhibition } \\
\text { (Stroop } \\
\text { color-word) }\end{array}$ & Yes \\
\hline & $\begin{array}{l}\text { Chronic meth } \\
\text { users (current) }\end{array}$ & $44(20 \%)$ & & & & & & & & \\
\hline \multirow[t]{3}{*}{ Andres et al. (38) } & Healthy & $34(38 \%)$ & & & & & & & Impulsivity (BIS) & $\begin{array}{l}\text { Yes, but only in } \\
\text { current users }\end{array}$ \\
\hline & $\begin{array}{l}\text { Chronic meth } \\
\text { users (current) }\end{array}$ & $27(44 \%)$ & & & & & & & & \\
\hline & $\begin{array}{l}\text { Chronic meth } \\
\text { users (abstinent } \\
1 \text { month- } \\
24 \text { years) }\end{array}$ & $32(37 \%)$ & & & & & & & & \\
\hline \multirow[t]{2}{*}{ Su et al. (39) } & Healthy & 346 ( 60\%) & $\begin{array}{l}\text { Verbal (RBANS; } \\
\text { OCL) }\end{array}$ & Yes & & & & & & \\
\hline & $\begin{array}{l}\text { Chronic meth } \\
\text { users (last use } \\
1-7 \text { days) }\end{array}$ & 178 ( 18\%) & & & & & & & & \\
\hline \multirow[t]{2}{*}{ Simon et al. (40) } & Healthy & $65(60 \%)$ & $\begin{array}{l}\text { Verbal; Visual } \\
\text { (repeated } \\
\text { memory test) }\end{array}$ & $\begin{array}{l}\text { Yes (verbal and } \\
\text { visual) }\end{array}$ & & & $\begin{array}{l}\text { Verbal (digit } \\
\text { span) }\end{array}$ & Yes & $\begin{array}{l}\text { Inhibition } \\
\text { (Stroop } \\
\text { color-word) }\end{array}$ & Yes \\
\hline & $\begin{array}{l}\text { Chronic meth } \\
\text { users (last use } \\
\text { within } 3 \text { days) }\end{array}$ & $65(45 \%)$ & & & & & & & & \\
\hline \multirow[t]{2}{*}{ Simon et al. (41) } & Healthy & $40(65 \%)$ & $\begin{array}{l}\text { Verbal; Visual } \\
\text { (repeated } \\
\text { memory test) }\end{array}$ & $\begin{array}{l}\text { Yes (verbal): } \\
\text { No (visual) }\end{array}$ & & & $\begin{array}{l}\text { Verbal (digit } \\
\text { span) }\end{array}$ & Yes & $\begin{array}{l}\text { Inhibition } \\
\text { (Stroop } \\
\text { color-word) }\end{array}$ & Yes \\
\hline & $\begin{array}{l}\text { Chronic meth } \\
\text { users (last use } \\
\text { within } 3 \text { days) }\end{array}$ & $40(50 \%)$ & & & & & & & & \\
\hline
\end{tabular}




\begin{tabular}{|c|c|c|c|c|c|c|c|c|c|c|}
\hline \multirow[t]{2}{*}{ Study } & \multirow[t]{2}{*}{ Sample } & \multirow[t]{2}{*}{ n (\% females) } & \multicolumn{2}{|c|}{ Learning and Memory } & \multicolumn{2}{|c|}{ Social Cognition } & \multicolumn{2}{|c|}{ Working Memory } & \multicolumn{2}{|c|}{ Inhibition \& Impulsive Control } \\
\hline & & & $\begin{array}{l}\text { Types } \\
\text { (measures) }\end{array}$ & $\begin{array}{l}\text { Impaired in } \\
\text { meth? }\end{array}$ & $\begin{array}{l}\text { Types } \\
\text { (measures) }\end{array}$ & $\begin{array}{l}\text { Impaired in } \\
\text { meth? }\end{array}$ & $\begin{array}{l}\text { Types } \\
\text { (measures) }\end{array}$ & $\begin{array}{l}\text { Impaired in } \\
\text { meth? }\end{array}$ & $\begin{array}{l}\text { Types } \\
\text { (measures) }\end{array}$ & $\begin{array}{l}\text { Impaired in } \\
\text { meth? }\end{array}$ \\
\hline \multirow[t]{3}{*}{$\begin{array}{l}\text { Monterosso et al. } \\
\text { (42) }\end{array}$} & $\begin{array}{l}\text { Healthy } \\
\text { (smokers) }\end{array}$ & & & & & & & & $\begin{array}{l}\text { Inhibition } \\
\text { (SSRT) }\end{array}$ & Yes \\
\hline & $\begin{array}{l}\text { Healthy } \\
\text { (non-smokers) }\end{array}$ & 29 (67\%) & & & & & & & & \\
\hline & $\begin{array}{l}\text { Chronic meth } \\
\text { users (last use } \\
5-7 \text { days) }\end{array}$ & $11(36 \%)$ & & & & & & & & \\
\hline \multirow[t]{2}{*}{ Thompson (22) } & Healthy & 21 (52\%) & $\begin{array}{l}\text { Visual (repeated } \\
\text { memory test) }\end{array}$ & Yes & & & & & & \\
\hline & $\begin{array}{l}\text { Chronic meth } \\
\text { users (last use } \\
19 \text { out of } 30 \text { days) }\end{array}$ & $22(32 \%)$ & & & & & & & & \\
\hline \multirow[t]{3}{*}{ ludicello et al. (43) } & Healthy & $\begin{array}{l}\text { Both times: } 38 \\
(8 \%)\end{array}$ & $\begin{array}{l}\text { Verbal; Visual } \\
\text { (BVMT-R; } \\
\text { HVLT-R) }\end{array}$ & $\begin{array}{l}\text { Baseline \& } \\
\text { follow-up: } \\
\text { Yes for non- } \\
\text { abstinent users } \\
\text { (visual, verbal) }\end{array}$ & & & $\begin{array}{l}\text { Verbal (PASAT; } \\
\text { LNS) }\end{array}$ & $\begin{array}{l}\text { Baseline \& } \\
\text { follow-up: No }\end{array}$ & & \\
\hline & $\begin{array}{l}\text { Chronic meth } \\
\text { users (baseline: } \\
\text { current; } \\
\text { follow-up: } \\
\text { non-abstinent) }\end{array}$ & $\begin{array}{l}\text { Both times: } 58 \\
(9 \%)\end{array}$ & & & & & & & & \\
\hline & $\begin{array}{l}\text { Chronic meth } \\
\text { users (baseline: } \\
\text { current; } \\
\text { follow-up: } \\
\text { abstinent } 1 \text { year) }\end{array}$ & $\begin{array}{l}\text { Both times: } 25 \\
(12 \%)\end{array}$ & & & & & & & & \\
\hline \multirow[t]{2}{*}{ Nestor et al. (23) } & Healthy & 18 (39\%) & & & & & & & $\begin{array}{l}\text { Inhibition } \\
\text { (Stroop } \\
\text { color-word) }\end{array}$ & Yes \\
\hline & $\begin{array}{l}\text { Chronic meth } \\
\text { users (abstinent } \\
4-7 \text { days) }\end{array}$ & 10 (50\%) & & & & & & & & \\
\hline \multirow[t]{2}{*}{ Simon et al. (44) } & Healthy & $\begin{array}{l}\text { Baseline: } \\
28 \text { (50\%) } \\
\text { Follow-up: } 21 \\
\text { (43\%) }\end{array}$ & $\begin{array}{l}\text { Verbal; Visual } \\
\text { (Repeated } \\
\text { memory test; } \\
\text { Selective } \\
\text { reminder test) }\end{array}$ & $\begin{array}{l}\text { Baseline \& } \\
\text { follow-up: No }\end{array}$ & & & $\begin{array}{l}\text { Verbal; Visual } \\
\text { (digit span; } \\
\text { reading span; } \\
\text { missing digit } \\
\text { span) }\end{array}$ & $\begin{array}{l}\text { Baseline \& } \\
\text { follow-up: No }\end{array}$ & $\begin{array}{l}\text { Inhibition } \\
\text { (Stroop } \\
\text { color-word) }\end{array}$ & $\begin{array}{l}\text { Baseline \& } \\
\text { follow-up: No }\end{array}$ \\
\hline & $\begin{array}{l}\text { Chronic meth } \\
\text { users (baseline: } \\
\text { abstinent 4-9 } \\
\text { days; follow-up: } \\
\text { abstinent } \\
1 \text { month) }\end{array}$ & $\begin{array}{l}\text { Baseline: } \\
27(37 \%) \\
\text { Follow-up: } 18 \\
(28 \%)\end{array}$ & & & & & & & & \\
\hline
\end{tabular}


TABLE 1 | Continued

\begin{tabular}{|c|c|c|c|c|c|c|c|c|c|c|}
\hline \multirow[t]{2}{*}{ Study } & \multirow[t]{2}{*}{ Sample } & \multirow[t]{2}{*}{ n (\% females) } & \multicolumn{2}{|c|}{ Learning and Memory } & \multicolumn{2}{|c|}{ Social Cognition } & \multicolumn{2}{|l|}{ Working Memory } & \multicolumn{2}{|c|}{ Inhibition \& Impulsive Control } \\
\hline & & & $\begin{array}{l}\text { Types } \\
\text { (measures) }\end{array}$ & $\begin{array}{l}\text { Impaired in } \\
\text { meth? }\end{array}$ & $\begin{array}{l}\text { Types } \\
\text { (measures) }\end{array}$ & $\begin{array}{l}\text { Impaired in } \\
\text { meth? }\end{array}$ & $\begin{array}{l}\text { Types } \\
\text { (measures) }\end{array}$ & $\begin{array}{l}\text { Impaired in } \\
\text { meth? }\end{array}$ & $\begin{array}{l}\text { Types } \\
\text { (measures) }\end{array}$ & $\begin{array}{l}\text { Impaired in } \\
\text { meth? }\end{array}$ \\
\hline \multirow[t]{2}{*}{$\begin{array}{l}\text { Kalechstein et al. } \\
\text { (45) }\end{array}$} & Healthy & $18(17 \%)$ & $\begin{array}{l}\text { Verbal; Visual } \\
\text { (AVLT; WMS; } \\
\text { CFT) }\end{array}$ & $\begin{array}{l}\text { Yes (verbal); } \\
\text { No (visual) }\end{array}$ & & & $\begin{array}{l}\text { Verbal; Visual } \\
\text { (LNS; VMS) }\end{array}$ & No & $\begin{array}{l}\text { Inhibition } \\
\text { (Stroop } \\
\text { color-word) }\end{array}$ & Yes \\
\hline & $\begin{array}{l}\text { Chronic meth } \\
\text { users (abstinent } \\
5-14 \text { days) }\end{array}$ & $27(30 \%)$ & & & & & & & & \\
\hline \multirow[t]{2}{*}{ Schwartz et al. (24) } & Healthy & $44(50 \%)$ & & & & & & & Impulsivity (DDT) & Yes \\
\hline & $\begin{array}{l}\text { Chronic meth } \\
\text { users (abstinent } \\
14-160 \text { days) }\end{array}$ & $61(49 \%)$ & & & & & & & & \\
\hline \multirow[t]{2}{*}{ Hoffman et al. (46) } & Healthy & $41(27 \%)$ & $\begin{array}{l}\text { Verbal (AVLT; } \\
\text { Babcock story } \\
\text { recall) }\end{array}$ & Yes & & & & & $\begin{array}{l}\text { Inhibition } \\
\text { (Stroop } \\
\text { color-word) }\end{array}$ & No \\
\hline & $\begin{array}{l}\text { Chronic meth } \\
\text { users (abstinent } \\
0.5-6 \text { months) }\end{array}$ & $41(24 \%)$ & & & & & & & & \\
\hline \multirow[t]{2}{*}{ Woods et al. (47) } & Healthy & $71(41 \%)$ & Verbal (HVLT-R) & Yes & & & & & & \\
\hline & $\begin{array}{l}\text { Chronic meth } \\
\text { users (abstinent } \\
0.2-18.2 \text { months) }\end{array}$ & $87(31 \%)$ & & & & & & & & \\
\hline \multirow[t]{2}{*}{$\begin{array}{l}\text { Van Der Plas } \\
\text { et al. (48) }\end{array}$} & Healthy & $36(47 \%)$ & & & & & $\begin{array}{l}\text { Visual (Tic tac } \\
\text { toe) }\end{array}$ & Yes & & \\
\hline & $\begin{array}{l}\text { Chronic meth } \\
\text { users (abstinent } \\
>15 \text { days) }\end{array}$ & 38 (66\%) & & & & & & & & \\
\hline \multirow[t]{2}{*}{ Boileau et al. (49) } & Healthy & $14(21 \%)$ & & & & & Verbal (digit span) & No & & \\
\hline & $\begin{array}{l}\text { Chronic meth } \\
\text { users (abstinent } \\
\sim 19 \text { days) }\end{array}$ & $16(31 \%)$ & & & & & & & & \\
\hline \multirow[t]{2}{*}{ Kim et al. (50) } & Healthy & $27(0 \%)$ & & & $\begin{array}{l}\text { Facial affect } \\
\text { recognition } \\
\text { (facial emotion } \\
\text { recognition } \\
\text { task; eye test; } \\
\text { hitting task) }\end{array}$ & Yes & & & & \\
\hline & $\begin{array}{l}\text { Chronic meth } \\
\text { users (abstinent } \\
\sim 20 \text { days) }\end{array}$ & $28(0 \%)$ & & & & & & & & \\
\hline \multirow[t]{2}{*}{ Uhlmann et al. (25) } & Healthy & $40(28 \%)$ & & & & & & & $\begin{array}{l}\text { Impulsivity } \\
\text { (UPPS-P impulsive } \\
\text { behavior scale) }\end{array}$ & Yes \\
\hline & $\begin{array}{l}\text { Chronic meth } \\
\text { users (abstinent } \\
\sim 21 \text { days) }\end{array}$ & $39(28 \%)$ & & & & & & & & \\
\hline
\end{tabular}




\begin{tabular}{|c|c|c|c|c|c|c|c|c|c|c|}
\hline \multirow[t]{2}{*}{ Study } & \multirow[t]{2}{*}{ Sample } & \multirow[t]{2}{*}{ n (\% females) } & \multicolumn{2}{|c|}{ Learning and Memory } & \multicolumn{2}{|c|}{ Social Cognition } & \multicolumn{2}{|c|}{ Working Memory } & \multicolumn{2}{|c|}{ Inhibition \& Impulsive Control } \\
\hline & & & $\begin{array}{l}\text { Types } \\
\text { (measures) }\end{array}$ & $\begin{array}{l}\text { Impaired in } \\
\text { meth? }\end{array}$ & $\begin{array}{l}\text { Types } \\
\text { (measures) }\end{array}$ & $\begin{array}{l}\text { Impaired in } \\
\text { meth? }\end{array}$ & $\begin{array}{l}\text { Types } \\
\text { (measures) }\end{array}$ & $\begin{array}{l}\text { Impaired in } \\
\text { meth? }\end{array}$ & $\begin{array}{l}\text { Types } \\
\text { (measures) }\end{array}$ & $\begin{array}{l}\text { Impaired in } \\
\text { meth? }\end{array}$ \\
\hline \multirow[t]{2}{*}{$\begin{array}{l}\text { Uhlmann et al. } \\
\text { (51) }\end{array}$} & Healthy & 21 (19\%) & & & $\begin{array}{l}\text { Facial affect } \\
\text { recognition; } \\
\text { Theory of } \\
\text { mind (emotion } \\
\text { recognition } \\
\text { task; mind in } \\
\text { the eyes test) }\end{array}$ & Yes & & & & \\
\hline & $\begin{array}{l}\text { Chronic meth } \\
\text { users (abstinent } \\
\sim 21 \text { days) }\end{array}$ & $21(19 \%)$ & & & & & & & & \\
\hline \multirow[t]{3}{*}{ Salo et al. (52) } & Healthy & $38(45 \%)$ & & & & & & & $\begin{array}{l}\text { Inhibition (Stroop } \\
\text { color-word) }\end{array}$ & $\begin{array}{l}\text { Yes, but only in } \\
\text { early abstinence }\end{array}$ \\
\hline & $\begin{array}{l}\text { Chronic meth } \\
\text { users (abstinent } \\
3 \text { weeks- } \\
6 \text { months) }\end{array}$ & 41 (54\%) & & & & & & & & \\
\hline & $\begin{array}{l}\text { Chronic meth } \\
\text { users (abstinent } \\
>1 \text { year) }\end{array}$ & $28(68 \%)$ & & & & & & & & \\
\hline \multirow[t]{2}{*}{$\begin{array}{l}\text { Gonzalez et al. } \\
\text { (53) }\end{array}$} & Healthy & $19(37 \%)$ & & & & & $\begin{array}{l}\text { Verbal (digit } \\
\text { span) }\end{array}$ & Yes & & \\
\hline & $\begin{array}{l}\text { Chronic meth } \\
\text { users (abstinent } \\
\sim 30 \text { day) }\end{array}$ & $16(25 \%)$ & & & & & & & & \\
\hline Morgan et al. (54) & $\begin{array}{l}\text { Healthy } \\
\text { Chronic meth } \\
\text { users (abstinent } \\
1.5-5 \text { months) }\end{array}$ & $\begin{array}{l}110(36 \%) \\
114(30 \%)\end{array}$ & Visual (BVMT-R) & Yes & & & & & & \\
\hline \multirow[t]{2}{*}{ Zhong et al. (32) } & Healthy & $\begin{array}{l}\text { Baseline: } 58 \\
\text { (36\%) Follow-up } \\
\text { 1: } 29 \text { Follow-up } \\
\text { 2: } 25\end{array}$ & $\begin{array}{l}\text { Verbal; Visual } \\
\text { (ISL; OCL) }\end{array}$ & $\begin{array}{l}\text { Baseline \& } \\
\text { follow-up 1: } \\
\text { Yes (verbal) } \\
\text { No (visual) } \\
\text { Follow-up 2: No } \\
\text { (verbal \& visual) }\end{array}$ & $\begin{array}{l}\text { Facial affect } \\
\text { recognition } \\
\text { (social emotion } \\
\text { cognitive task) }\end{array}$ & $\begin{array}{l}\text { Baseline: Yes } \\
\text { Follow-up } 1 \text { \& } \\
\text { 2: No }\end{array}$ & $\begin{array}{l}\text { Visual (CPAL; } \\
\text { 2-back task) }\end{array}$ & $\begin{array}{l}\text { Baseline: Yes } \\
\text { Follow-up } 1 \& \text { } \\
\text { 2: No }\end{array}$ & & \\
\hline & $\begin{array}{l}\text { Chronic meth } \\
\text { users (baseline: } \\
\text { abstinent } \\
\sim 1.5 \text { months; } \\
\text { follow-up } \\
\text { 1: abstinent } \\
\sim 4.5 \text { months; } \\
\text { follow-up 2: } \\
\text { abstinent 7.5 } \\
\text { months) }\end{array}$ & $\begin{array}{l}\text { Baseline: } 54 \\
\text { (26\%) Follow-up } \\
\text { 1: } 44 \text { Follow-up } \\
\text { 2: } 35\end{array}$ & & & & & & & & \\
\hline
\end{tabular}


TABLE 1 | Continued

\begin{tabular}{|c|c|c|c|c|c|c|c|c|c|c|}
\hline \multirow[t]{2}{*}{ Study } & \multirow[t]{2}{*}{ Sample } & \multirow[t]{2}{*}{ n (\% females) } & \multicolumn{2}{|c|}{ Learning and Memory } & \multicolumn{2}{|c|}{ Social Cognition } & \multicolumn{2}{|c|}{ Working Memory } & \multicolumn{2}{|c|}{ Inhibition \& Impulsive Control } \\
\hline & & & $\begin{array}{l}\text { Types } \\
\text { (measures) }\end{array}$ & $\begin{array}{l}\text { Impaired in } \\
\text { meth? }\end{array}$ & $\begin{array}{l}\text { Types } \\
\text { (measures) }\end{array}$ & $\begin{array}{l}\text { Impaired in } \\
\text { meth? }\end{array}$ & $\begin{array}{l}\text { Types } \\
\text { (measures) }\end{array}$ & $\begin{array}{l}\text { Impaired in } \\
\text { meth? }\end{array}$ & $\begin{array}{l}\text { Types } \\
\text { (measures) }\end{array}$ & $\begin{array}{l}\text { Impaired in } \\
\text { meth? }\end{array}$ \\
\hline \multirow[t]{2}{*}{ Salo et al. (55) } & Healthy & $12(0 \%)$ & & & & & & & $\begin{array}{l}\text { Inhibition } \\
\text { (Stroop } \\
\text { color-word) }\end{array}$ & Yes \\
\hline & $\begin{array}{l}\text { Chronic meth } \\
\text { users (abstinent } \\
2-4 \text { months) }\end{array}$ & $8(0 \%)$ & & & & & & & & \\
\hline \multirow[t]{2}{*}{ Salo et al. (56) } & Healthy & $16(50 \%)$ & & & & & & & $\begin{array}{l}\text { Inhibition } \\
\text { (Stroop } \\
\text { color-word) }\end{array}$ & Yes \\
\hline & $\begin{array}{l}\text { Chronic meth } \\
\text { users (abstinent } \\
2-12 \text { months) }\end{array}$ & $12(58 \%)$ & & & & & & & & \\
\hline \multirow[t]{2}{*}{ Kim et al. (57) } & Healthy & & & & & & & & $\begin{array}{l}\text { Inhibition } \\
\text { (WCST) }\end{array}$ & Yes \\
\hline & $\begin{array}{l}\text { Chronic meth } \\
\text { users (abstinent } \\
2.6-30.6 \text { months) }\end{array}$ & $29(7 \%)$ & & & & & & & & \\
\hline \multirow[t]{2}{*}{ Rendell et al. (58) } & Healthy & 20 (40\%) & $\begin{array}{l}\text { Verbal; Visual } \\
\text { (AVLT; virtual } \\
\text { week) }\end{array}$ & Yes & & & $\begin{array}{l}\text { Verbal (digit } \\
\text { span) }\end{array}$ & Yes & & \\
\hline & $\begin{array}{l}\text { Chronic meth } \\
\text { users (abstinent } \\
3-8 \text { months) }\end{array}$ & 20 (40\%) & & & & & & & & \\
\hline \multirow[t]{2}{*}{ Henry et al. (59) } & Healthy & $20(40 \%)$ & Verbal (AVLT) & Yes & $\begin{array}{l}\text { Facial affect } \\
\text { recognition; } \\
\text { Theory of mind } \\
\text { (facial affect } \\
\text { test; mind in } \\
\text { the eyes test) }\end{array}$ & Yes & & & & \\
\hline & $\begin{array}{l}\text { Chronic meth } \\
\text { users (abstinent } \\
3-8 \text { months) }\end{array}$ & $20(40 \%)$ & & & & & & & & \\
\hline \multirow[t]{2}{*}{$\begin{array}{l}\text { Johanson et al. } \\
\text { (60) }\end{array}$} & Healthy & $18(33 \%)$ & Verbal (CVLT) & Yes & & & $\begin{array}{l}\text { Visual (SWM; } \\
\text { DMS) }\end{array}$ & No & & \\
\hline & $\begin{array}{l}\text { Chronic meth } \\
\text { users (abstinent } \\
0.25-18 \text { years) }\end{array}$ & $16(31 \%)$ & & & & & & & & \\
\hline \multirow[t]{2}{*}{ ludicello et al. (61) } & Healthy & $26(8 \%)$ & $\begin{array}{l}\text { Prospective } \\
\text { (MIST) }\end{array}$ & Yes & & & & & & \\
\hline & $\begin{array}{l}\text { Chronic meth } \\
\text { users (abstinent } \\
\sim 105 \text { days) }\end{array}$ & 39 (58\%) & & & & & & & & \\
\hline
\end{tabular}


TABLE 1 | Continued

\begin{tabular}{|c|c|c|c|c|c|c|c|c|c|c|}
\hline \multirow[t]{2}{*}{ Study } & \multirow[t]{2}{*}{ Sample } & \multirow[t]{2}{*}{ n (\% females) } & \multicolumn{2}{|c|}{ Learning and Memory } & \multicolumn{2}{|c|}{ Social Cognition } & \multicolumn{2}{|c|}{ Working Memory } & \multicolumn{2}{|c|}{ Inhibition \& Impulsive Control } \\
\hline & & & $\begin{array}{l}\text { Types } \\
\text { (measures) }\end{array}$ & $\begin{array}{l}\text { Impaired in } \\
\text { meth? }\end{array}$ & $\begin{array}{l}\text { Types } \\
\text { (measures) }\end{array}$ & $\begin{array}{l}\text { Impaired in } \\
\text { meth? }\end{array}$ & $\begin{array}{l}\text { Types } \\
\text { (measures) }\end{array}$ & $\begin{array}{l}\text { Impaired in } \\
\text { meth? }\end{array}$ & $\begin{array}{l}\text { Types } \\
\text { (measures) }\end{array}$ & $\begin{array}{l}\text { Impaired in } \\
\text { meth? }\end{array}$ \\
\hline \multirow[t]{2}{*}{ Cherner et al. (62) } & Healthy & $46(50 \%)$ & $\begin{array}{l}\text { Verbal; Visual } \\
\text { (BVMT-R; } \\
\text { HVLT-R; story } \\
\text { memory test; } \\
\text { figure memory } \\
\text { test) }\end{array}$ & Yes & & & $\begin{array}{l}\text { Verbal (PASAT; } \\
\text { LNS) }\end{array}$ & No & $\begin{array}{l}\text { Inhibition } \\
\text { (Stroop } \\
\text { color-word) }\end{array}$ & No \\
\hline & $\begin{array}{l}\text { Chronic } \\
\text { meth users } \\
\text { (abstinent } \\
\sim 4 \text { months) }\end{array}$ & $54(26 \%)$ & & & & & & & & \\
\hline \multirow[t]{2}{*}{ Rippeth et al. (63) } & Healthy & 60 (50\%) & $\begin{array}{l}\text { Verbal; Visual } \\
\text { (BVMT-R; } \\
\text { HVLT-R) }\end{array}$ & Yes & & & $\begin{array}{l}\text { Verbal (PASAT; } \\
\text { LNS) }\end{array}$ & Yes & & \\
\hline & $\begin{array}{l}\text { Chronic } \\
\text { meth users } \\
\text { (abstinent } \\
\sim 4.5 \text { months) } \\
\end{array}$ & $47(36 \%)$ & & & & & & & & \\
\hline \multirow[t]{2}{*}{ Chang et al. (64) } & Healthy & $20(50 \%)$ & Verbal (AVLT) & No & & & $\begin{array}{l}\text { Visual (One- } \\
\text { back task) }\end{array}$ & No & & \\
\hline & $\begin{array}{l}\text { Chronic } \\
\text { meth users } \\
\text { (abstinent } \\
6-8 \text { months) }\end{array}$ & $20(50 \%)$ & & & & & & & & \\
\hline \multirow[t]{2}{*}{ King et al. (65) } & Healthy & 74 (50\%) & & & & & & & $\begin{array}{l}\text { Inhibition } \\
\text { (Stroop } \\
\text { color-word) }\end{array}$ & Yes \\
\hline & $\begin{array}{l}\text { Chronic } \\
\text { meth users } \\
\text { (abstinent } \\
\sim 252 \text { days) }\end{array}$ & $54(68 \%)$ & & & & & & & & \\
\hline \multirow[t]{3}{*}{ Stock et al. (66) } & Healthy & 32 & & & & & $\begin{array}{l}\text { Verbal; Visual } \\
\text { (digit span; } \\
\text { Corsi block } \\
\text { span) }\end{array}$ & No & $\begin{array}{l}\text { Inhibition } \\
\text { (Stroop } \\
\text { color-word) }\end{array}$ & $\begin{array}{l}\text { Yes, but only in } \\
\text { early abstinence }\end{array}$ \\
\hline & $\begin{array}{l}\text { Chronic } \\
\text { meth users } \\
\text { (abstinent } \\
\sim 9.9 \text { months) }\end{array}$ & $13(38 \%)$ & & & & & & & & \\
\hline & $\begin{array}{l}\text { Chronic } \\
\text { meth users } \\
\text { (abstinent } \\
\sim 47.6 \text { months) }\end{array}$ & $14(43 \%)$ & & & & & & & & \\
\hline
\end{tabular}




\begin{tabular}{|c|c|c|c|c|c|c|c|c|c|c|}
\hline \multirow[t]{2}{*}{ Study } & \multirow[t]{2}{*}{ Sample } & \multirow[t]{2}{*}{ n (\% females) } & \multicolumn{2}{|c|}{ Learning and Memory } & \multicolumn{2}{|c|}{ Social Cognition } & \multicolumn{2}{|c|}{ Working Memory } & \multicolumn{2}{|c|}{ Inhibition \& Impulsive Contro } \\
\hline & & & $\begin{array}{l}\text { Types } \\
\text { (measures) }\end{array}$ & $\begin{array}{l}\text { Impaired in } \\
\text { meth? }\end{array}$ & $\begin{array}{l}\text { Types } \\
\text { (measures) }\end{array}$ & $\begin{array}{l}\text { Impaired in } \\
\text { meth? }\end{array}$ & $\begin{array}{l}\text { Types } \\
\text { (measures) }\end{array}$ & $\begin{array}{l}\text { Impaired in } \\
\text { meth? }\end{array}$ & $\begin{array}{l}\text { Types } \\
\text { (measures) }\end{array}$ & $\begin{array}{l}\text { Impaired in } \\
\text { meth? }\end{array}$ \\
\hline \multirow[t]{2}{*}{ Salo et al. (26) } & Healthy & 30 (43\%) & & & & & & & $\begin{array}{l}\text { Inhibition } \\
\text { (Stroop } \\
\text { color-word) }\end{array}$ & Yes \\
\hline & $\begin{array}{l}\text { Chronic } \\
\text { meth users } \\
\text { (abstinent } \\
\sim 13.7 \text { months) }\end{array}$ & $30(50 \%)$ & & & & & & & & \\
\hline \multirow[t]{2}{*}{$\begin{array}{l}\text { Gonzalez et al. } \\
\text { (67) }\end{array}$} & Healthy & 41 (51\%) & $\begin{array}{l}\text { Verbal; Visual } \\
\text { (HVLT-R; } \\
\text { BVMT-R; story } \\
\text { memory test; } \\
\text { figure memory } \\
\text { test) }\end{array}$ & Yes & & & $\begin{array}{l}\text { Verbal (PASAT, } \\
\text { LNS) }\end{array}$ & No & & \\
\hline & $\begin{array}{l}\text { Chronic } \\
\text { meth users } \\
\text { (abstinent up to } \\
18 \text { months) }\end{array}$ & $26(46 \%)$ & & & & & & & & \\
\hline \multirow[t]{2}{*}{ Salo et al. (68) } & Healthy & $16(50 \%)$ & & & & & & & $\begin{array}{l}\text { Inhibition } \\
\text { (Stroop } \\
\text { color-word) }\end{array}$ & Yes \\
\hline & $\begin{array}{l}\text { Chronic } \\
\text { meth users } \\
\text { (abstinent } \\
\sim 20 \text { months) }\end{array}$ & $36(64 \%)$ & & & & & & & & \\
\hline \multirow[t]{2}{*}{ Salo et al. (69) } & Healthy & $17(47 \%)$ & & & & & & & $\begin{array}{l}\text { Inhibition } \\
\text { (Stroop } \\
\text { color-word) }\end{array}$ & Yes \\
\hline & $\begin{array}{l}\text { Chronic meth } \\
\text { users (abstinent } \\
\sim 20.98 \text { months) }\end{array}$ & 37 (65\%) & & & & & & & & \\
\hline \multirow[t]{2}{*}{ Moon et al. (70) } & Healthy & $18(0 \%)$ & $\begin{array}{l}\text { Verbal; Visual } \\
\text { (AVLT; CFT) }\end{array}$ & $\begin{array}{l}\text { Yes (verbal); } \\
\text { No (visual) }\end{array}$ & & & & & & \\
\hline & $\begin{array}{l}\text { Chronic } \\
\text { meth users } \\
\text { (abstinent } \\
\sim 1.79 \text { years) }\end{array}$ & $19(0 \%)$ & & & & & & & & \\
\hline
\end{tabular}

ANT, attention networks task; AVLT, auditory verbal learning test; BIS, Barratt impulsiveness scale; BVMT-R, brief visuospatial memory test-revised; CFT, complex figure test; CPAL, continuous paired association learning task; CPT, continuous performance test; CVLT, California verbal learning test; DDT, delayed discounting task; DNM, delayed non-match to sample task; DMS, delayed match to sample; HVLT-R, Hopkins verbal learning test-revisited; ISL, international shopping list task; LNS, letter-number sequence; MIST, memory for intentions screening test; OCL, one card learning task; PASAT, paced auditory serial addition task; RBANS; repeatable battery for the assessment of neuropsychological status; SCAP, spatial capacity delayed response test; SSRT; stop-signal reaction time; SWM, spatial working memory span; VMS, visual memory span; WCST, Wisconsin card sorting test; WMS, Wechsler memory scale. 
pathophysiology of schizophrenia (75), which may cause neural dysfunction associated with cognition overlapping with chronic meth use. A meta-analysis reported that people with meth use disorder show deficits of medium effect size in cognition (76). In people with schizophrenia, impairments of medium to large effect sizes are observed in similar domains (77).

The scope and breadth of cognition studies in meth use disorder are severely lacking compared to schizophrenia. Thus, the present review specifically highlights dominantly studied aspects of cognition in chronic meth use, namely learning and memory, social cognition, and two key executive functions: working memory and inhibitory/impulsive control. The findings are then compared against corresponding studies in schizophrenia.

\section{Learning and Memory}

While all types of memory are not yet assessed in meth use disorder, there is strong evidence that both current and abstinent meth users display mild impairments in visual, verbal, and prospective learning and memory $(22,32,39-41,43-47,54$, $58-63,67,70)$, even observed after 1.8 years of abstinence (Table 1). People with schizophrenia display severe impairments in similar domains examined using the same tests (78-80). Prospective memory impairments are of particular interest because they are negatively associated with treatment outcomes due to poorer adherence to medication regimens (81) and greater likelihood of missed appointments (79).

While it is difficult to establish meth dependence in animals, preclinical rodent studies using chronic meth exposure (minimum 7 days of exposure) suggest a long-lasting causative effect of meth on different types of learning and memory. Meth self-administrating rats display both short- and long-term impairments in recognition memory $(82,83)$. In contrast, experimenter-led chronic injections of meth only impairs long-term recognition memory (84). In a study investigating the effect of meth on auditory associative learning and memory, experimenter-led chronic injections of meth disrupted recall of inhibitory memory, whereas meth self-administration disrupted associative learning (85). Spatial memory impairments are also observed in self-administrating rats and rats subject to experimenter-led chronic injections (86-88), with effects lasting up to 3 weeks following abstinence (89). In contrast, a study by Kesby and colleagues (90) found that experimenter-led chronic meth injections may improve learning in mice in a visual discrimination task (90). Taken together, it may be that chronic meth injections may initially improve learning processes but lead to deficits in the long-term, whereas meth self-administration consistently lead to memory impairments.

Learning and memory processes rely on the prefrontal cortex (PFC) and medial temporal lobe including the hippocampus (91). Altered structure and activity of these regions have been described in both meth use disorder and schizophrenia that may be associated with poorer memory. For example, a MRI study showed an association between decreased bilateral hippocampal volume and poorer performance on a word-recall task in current meth users (22), although a recent study with bigger sample size failed to find a link between visual/verbal memory and hippocampal volume in abstinent meth dependents (92). In schizophrenia, the association between decreased bilateral hippocampal volume and poorer performance on a verbal recall task is well established (93). This suggests a shared role for hippocampal volume reduction in verbal learning and memory impairments in both disorders.

No study has investigated the neural correlates of prospective memory performance in people with meth use disorder, but there is one study in people with schizophrenia. Chen et al. (29) found that compared to healthy controls, people with schizophrenia displayed hypoactivity in the frontal, parietal and temporal cortex (29). Indeed, prospective memory performance and activation of the rostral PFC and parietal lobe are positively associated in healthy people (94). People with meth use disorder or schizophrenia display reduced gray matter in the parietal lobe $(35,95,96$,$) , which may explain the visual learning and memory$ deficits observed. In addition, parietal gray matter reduction is observed in people with childhood-onset schizophrenia (95) and adolescents with meth use disorder (35). These findings suggest a role for parietal lobe that may be an early-onset risk factor for both disorders that may be targeted for treatment in childhood/adolescence.

\section{Social Cognition}

A recent meta-analysis in people with meth use disorder found that social cognition impairments were amongst the largest cognitive deficits observed, specifically in theory of mind (ToM) and emotion processing (76), which are also widely described in schizophrenia $(97,98)$. There is mice evidence suggesting a link between chronic meth injections during mid-late adolescence and disruption of social interaction following 2 weeks of abstinence in males (99). While social cognition deficits are apparent in current and short-term abstinent meth dependents $(32,50,51)$, there is conflicting evidence following long-term abstinence. For example, Henry et al. (59) found impairments of large effect size in participants with meth use disorder who have been abstinent for 3-8 months compared to healthy controls (59), whereas Zhong et al. (32) observed no differences after 7.5 months of abstinence (32). Given that social cognition deficits have a significant negative impact on social and vocational functioning in people with schizophrenia $(100,101)$, it is clear that further research of the deficit and its functional implications is warranted in people with meth use disorder.

Key brain structures underlying social cognition include ventro- and dorsolateral PFC (vlPFC and dlPFC), orbitofrontal cortex, anterior cingulate cortex (ACC), insular cortex, and amygdala (102-104). Indeed, alterations in those regions underlying social cognition are observed in meth use disorder and schizophrenia. Compared to healthy controls, there is reduced activation of the vlPFC and dlPFC in meth dependents $(105,106)$ and people with schizophrenia $(107,108)$ in response to threatening or fearful faces. Such prefrontal dysfunction may indicate failure to integrate socio-emotional information (109). People with schizophrenia also display hypoactivity of the cingulate cortex in response to negative words (107). In contrast, hyperactivity of the ACC and posterior cingulate cortex (PCC) is associated with response to negative emotions 
in people with meth use disorder $(105,106)$. Considering that ACC hyperactivity is linked to hypersensitivity to threat (106) and PCC hyperactivity is linked with recollection of past negative memories (105), it may be that emotional processing deficits arises from hyposensitivity to threat/sadness in schizophrenia but hypervigilance/distraction to threat/sadness in meth use disorder. This has important treatment implications and should be investigated.

Bilateral insular hypoactivity is observed in people with meth use disorder when presented with fearful and threatening images (105). Similarly in schizophrenia, left insular hypoactivity is associated with happy and fearful facial expression processing (110, 111), and disgust facial expressions in non-paranoid people with schizophrenia (112). Left insular hypoactivity when presented with sad faces is associated with adolescent-onset schizophrenia (113), which suggests that insular hypoactivity to sad faces may also be involved in adolescent-onset meth use. Consistent with functional MRI (fMRI) findings, insular cortex gray matter volume reduction is also observed in people with meth use disorder $(24,114,115)$ or schizophrenia $(95,116)$. In fact, a meta-analysis revealed that insular gray matter showed the largest decrease of all brain regions in people with schizophrenia (96), with larger volume reduction in the anterior compared to the posterior insular cortex (117). Such insular abnormalities in both disorders may be linked to decreased empathy and abnormal response to threatening situations (105).

While a recent neuroimaging meta-analysis revealed large decreases in insular and bilateral medial PFC activation during ToM tasks in people with schizophrenia (118), no studies have investigated the neural correlate of ToM impairments in people with meth use disorder. ToM deficits appear consistent in meth use disorder, thus it would be interesting to examine whether its neural correlates are shared with people with schizophrenia.

\section{Executive Functions: Working Memory and Inhibitory Control}

Executive functions are high-order cognitive processes necessary to balance new ideas, think before acting, remain focused, and resist temptations to ultimately control behaviors such as decision making (119). Such cognitive processes include inhibitory control, working memory, attentional control, and cognitive flexibility. Moderate to severe impairments in working memory and inhibitory control have been described in meth use disorder and schizophrenia (76, 120-123). Longitudinal evidence suggests that executive function impairments may predispose individuals to developing schizophrenia (124). While there is no such study in people with meth use disorder, a rodent study showed that reduced executive function leads to increased meth selfadministration (125), suggesting that individual differences in executive function may contribute to the development and maintenance of meth dependence. This review will focus working memory and inhibitory control because other types of executive function have not been as thoroughly assessed in people diagnosed with meth use disorder.

\section{Working Memory}

Some studies have reported an association between working memory impairments and meth dependence in both current (40, $41,53)$ and abstinent $(32,43,48,58,62,63,66)$ chronic meth users, whereas others have found no association $(44,45,49,60,64,67)$. Although this may be due to different periods of abstinence across studies, inconsistent findings are still observed across studies with similar length of abstinence (Table 1). Additionally, some of the strongest effects of meth use on working memory were found in polydrug users $(53,63)$. Nevertheless, a meta-analysis recently revealed a moderate overall deficit in working memory in meth use disorder (76). In addition, male rats receiving chronic meth injections show long-lasting impairments in spatial working memory $(126,127)$. Given that impaired working memory in meth users is associated with disrupted social adaptation, global functioning, and unemployment $(31,32)$, more research is needed to elucidate whether such deficits are a predictor for the development of meth use disorder or a consequence of chronic meth use. In schizophrenia, working memory deficits form a core feature $(120,121)$, and premorbid working memory may be one of the most prominent factors predisposing individuals to developing the disorder $(124,128)$.

Studies focusing on working memory processes observed both hyper- and hypoactivation of the dlPFC in people with schizophrenia (27). Discrepancies between studies may to be due to varying task difficulty across studies (27), suggesting an association between dlPFC activation and degree of working memory impairments. We are not aware of an fMRI investigation during working memory tasks in people with meth use disorder. However, a perfusion MRI study found a positive correlation between working memory performance and regional cerebral flow in the left temporoparietal region and in the right lateral parietal cortex of abstinent meth users (64). Given that not all people with meth use disorder display impairments in working memory (Table 1), it would be informative to investigate individual patterns of frontal lobe dysfunction associated with such deficits and investigate whether a hyper- or hypoactivity emerges.

\section{Inhibitory Control}

The Stroop task, which measures the ability to suppress irrelevant information, is one of the most commonly used tests of inhibitory control in neuropsychiatric patients. Chronic meth use is associated with poorer performance in the Stroop task in adolescents $(35,37,65)$ and adults with meth use disorder $(23,26$, $34,40,41,45,66-52)$. Effects in adolescents suggest that reduced inhibitory control may be a predisposing factor to developing meth use disorder. There is extensive evidence that schizophrenia also leads to poorer performance on the Stroop task compared to controls (122, 123). Salo et al. (2011) explicitly compared Stroop performance between people with schizophrenia and people with meth use disorder, and found greater inhibitory deficits in early abstinent (2-7 days) meth dependents compared to schizophrenia patients (52). This suggests that withdrawal from meth may contribute to the severity of cognitive symptoms because the inhibition deficits and withdrawal symptoms decreased over time (52). Inhibitory control and impulsivity are 
associated (129). Indeed, people with schizophrenia or meth use disorder both display poor impulse control $(24,25,36,38$, $42,130,131)$. Notably, impulse-related functions are among the most impaired in meth use disorder (76), and poor impulsivity is regarded as one key predisposing factor to developing substance use disorder (132). In addition, Monterroso et al. (42) found that reaction time in an impulse control task positively correlates with grams of meth used per week, highlighting the relationship between poor impulse control performance and the extent of recent meth use (42). These deficits have important clinical implications. In meth use disorder, impaired inhibition is linked with unemployment (31), and poor impulse control is associated with treatment non-completion (133) and relapse (134). In schizophrenia, poorer inhibition and greater impulsivity have a negative impact on daily function $(135,136)$. In rodents, chronic meth injections lead to an age-dependent impairment in inhibition $(78,130)$. Interestingly, this effect is not observed after a week of withdrawal (131), suggesting that abstinence may reverse deficits in inhibition.

Inhibitory control impairments correlate with reduced gray matter volume in the middle frontal gyrus in meth use disorder (57). In schizophrenia, a reduction in orbital inferior frontal gray matter is observed (137). Disrupted frontal white matter integrity is linked with impulsivity (25) and inhibition (35) in meth use disorder. Meth dependents also display structural abnormalities in the genu of the corpus callosum $(138,139)$, a white matter tract which carries fibers originating from the PFC. Poorer corpus callosum integrity is associated with impaired inhibition $(140,141)$ and impulse control (38). In addition to structural abnormalities, people with meth use disorder display reduced activation of the PFC when performing the Stroop task (56), more specifically in the right inferior frontal gyrus (IFG), ACC (23) and the PFC (26). Likewise, people with schizophrenia display hypoactivity of the right IFG, ACC, and PFC when performing similar tasks $(28,142)$. Hypoactivity in the ACC and right IFG is also observed in people with early onset schizophrenia (143). It would be important to also examine these brain regions during executive function tasks in people with adolescent- vs adultonset of meth use disorder.

Metabolic alteration of the ACC is also associated with impaired inhibitory control in both disorders, which is measured by levels of $\mathrm{N}$-acetylaspartate, a marker of neuronal integrity (144). Reduced $N$-acetylaspartate levels in the ACC are observed in meth use disorder (145) and schizophrenia (146-149). $\mathrm{N}$-acetylaspartate levels correlate with poorer attention and inhibition in adult (68) and adolescent (37) meth users, and people with schizophrenia (150-152). Interestingly, reduced $\mathrm{N}$-acetylaspartate in ACC is more dramatic with early onset of meth use (37), and reduced ACC levels of $\mathrm{N}$-acetylaspartate are present at the early stages of schizophrenia (149), and in highrisk offspring of schizophrenia patients (152).

Taken together, impairments in learning and memory, social cognition, working memory and inhibitory control are observed in schizophrenia and meth use disorder. Such deficits affect treatment completion and outcomes in both conditions $(31,32,79,81,100,135,136)$. While there is evidence that cognitive deficits may be a risk factor for the development of schizophrenia, it remains unclear whether they predispose an individual towards meth dependence or are the result of chronic meth use. Brain studies suggest that people with schizophrenia and meth use disorder display largely similar patterns of structural and functional brain abnormalities in regions involved in key cognitive processes, with the exception of brain regions underlying emotion regulation (Figure 2). Such abnormalities may predict disease progression. What is clear from all the existing studies of cognition and related brain regions in meth use disorder is how much the findings overlap with corresponding studies in schizophrenia, with far more similarities compared to differences between the two disorders. This is in contrast to the many symptomatic differences between the two disorders $(7,153)$. While we do not know the mechanisms underlying such similarities in cognitive deficits and brain dysfunction, such overlaps provide an important opportunity to consider employing existing schizophrenia therapies for people with meth use disorder.

\section{INTERVENTIONS TO IMPROVE COGNITION IN METH USE DISORDER: INSIGHTS FROM SCHIZOPHRENIA RESEARCH}

The use of various pharmacotherapies to improve cognition in people with schizophrenia have yielded mixed results. A metaanalysis revealed that medication targeting the cholinergic system result in marginal improvement in verbal and spatial learning and memory (154). Preliminary evidence also suggest that oxytocin may improve social cognition and verbal learning and memory (155), but the efficacy of such intervention has proven to be inconclusive and more research is still needed (101). Results from a large scale multisite study suggests that treatment with antipsychotic medication only results in limited cognitive improvement (156). In addition to pharmacological treatments, a recent systematic review found that repeated transcranial magnetic stimulation may be beneficial in improving verbal and working memory, but not other functions such as cognitive flexibility (157).

On the other hand, CRT has shown promising results in the alleviation of cognitive deficits, with several meta-analyses revealing improvement of medium effect sizes in people with schizophrenia $(158,159)$. The Cognitive Remediation Experts Workshop (Florence, Italy, 2010) defines CRT as a "behavioral training-based intervention that aims to improve cognitive processes with the goal of durability and generalization". A range of CRTs have been developed over the past 50 years to target cognitive symptoms specifically in schizophrenia, with CRT well received by participants $(160,161)$. CRTs use diverse methods, such as drill and practice exercises, cognitive strategies training, and group discussions $(159,162)$. Consistent with the present review's observations that cognitive deficits overlap in schizophrenia and meth use disorder, preliminary evidence suggests that CRTs are also beneficial in people with meth use disorder $(163,164)$. Especially exciting are the results of two metaanalyses in schizophrenia patients that revealed CRT increased 


\section{Meth Use Disorder}

\section{Schizophrenia}

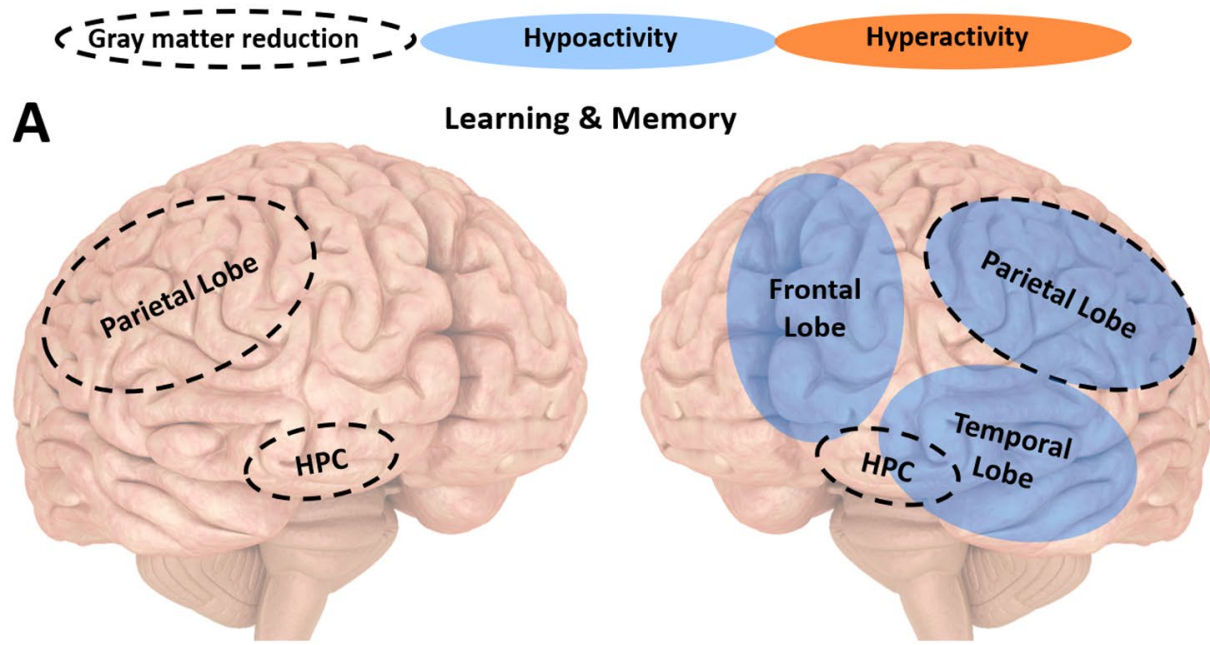

B

Social Cognition
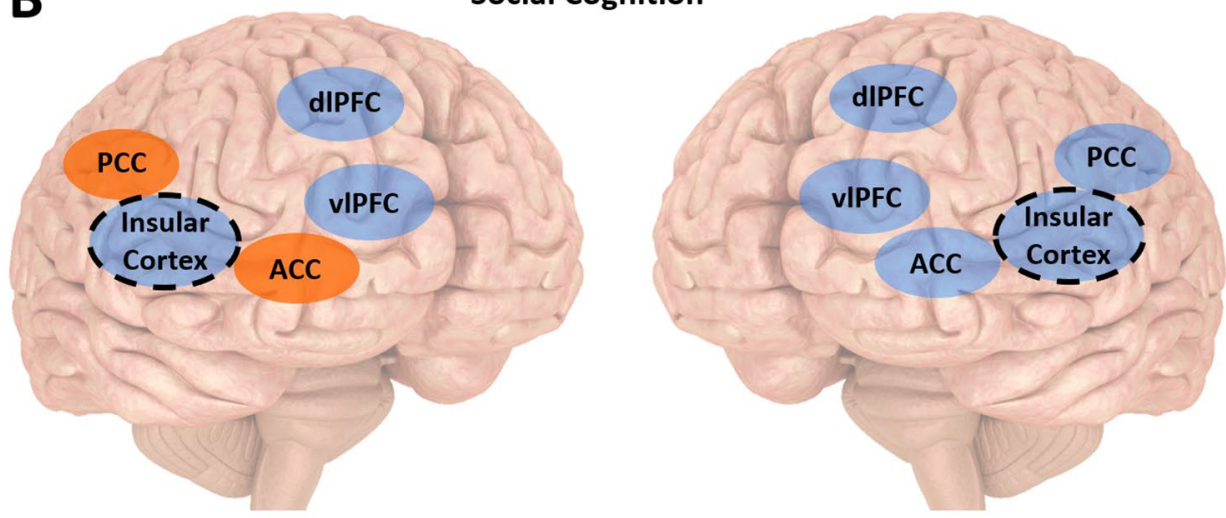

C

Executive Function
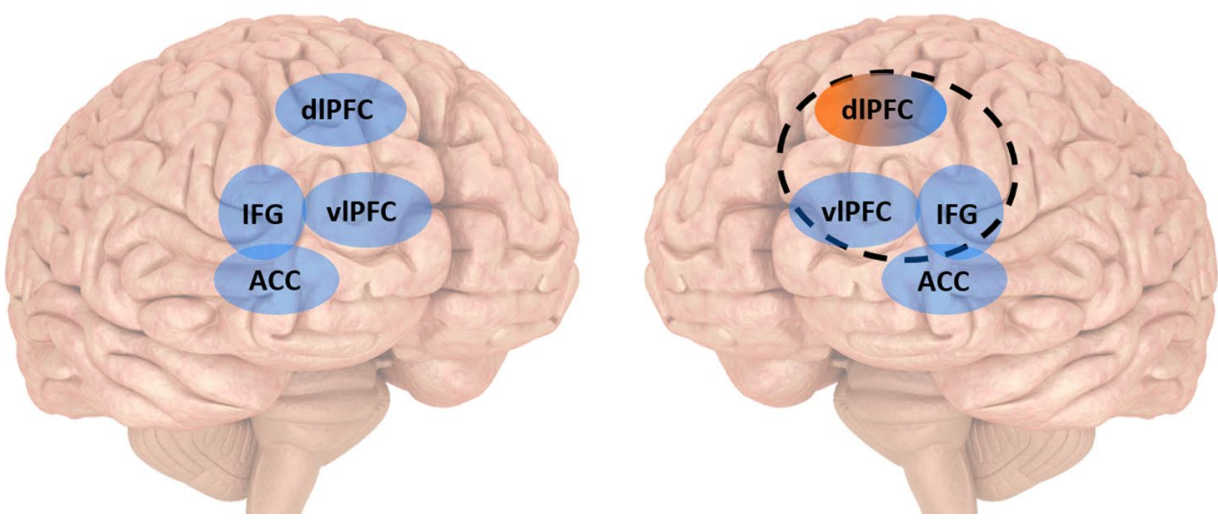

FIGURE 2 | Summary of the neurobiology underlying cognitive impairments in meth use disorder and schizophrenia. (A) People with meth use disorder or schizophrenia display similar patterns of gray matter reduction associated with learning and memory impairments in the hippocampus (HPC) and parietal lobe. People with schizophrenia also display reduced activity in the frontal, parietal and temporal lobes. (B) People with meth use disorder or schizophrenia display similar patterns of gray matter reduction associated with social cognition impairments in the insular cortex. They also display reduced activity in the dorsolateral and ventrolateral prefrontal cortices (dIPFC and vIPFC, respectively). They display opposite patterns of activity in the anterior and posterior cingulate cortices (ACC and PCC, respectively). (C) People with meth use disorder or schizophrenia display similar reduced activity in the vIPFC, ACC and inferior frontal gyrus (IFG) associated with executive dysfunction. People with schizophrenia may display dIPFC hypo- or hyperactivity, depending on task difficulty and working memory load. Executive dysfunction is also associated with reduced medial frontal gyrus (MFG) gray matter in people with meth use disorder, and reduced orbital IFG gray matter in people with schizophrenia. 
activation of brain regions affected in meth use disorder such as the dlPFC, mPFC, parietal cortex, insula, and thalamus (165, 166), and increased white matter integrity of the corpus callosum was also observed (167), highlighting that CRT may address the neurobiology underlying cognitive impairments. Overall, CRT has been shown to more consistently improve cognition in people with schizophrenia compared to other therapeutics avenues, with effect sizes varying between domains. CRT will therefore be the focus of this review.

\section{Targeting Learning and Memory Deficits}

Improvements in verbal memory are observed in people with schizophrenia following CRT $(158,159)$. There is also evidence that cognitive training may improve event-based prospective memory in people with schizophrenia (80). Although prospective memory training appears to be a promising treatment approach, effect on daily function and functional outcome has yet to be investigated in schizophrenia.

To the best of our knowledge, similar memory training in people with meth use disorder has not yet been described. Given the negative impact of poor prospective memory on treatment outcome, it would be beneficial to consider developing CRT targeting such deficits in meth use disorders. CRT focusing on verbal and prospective memory training may be the most effective to treat meth use disorder because visual learning and memory is one of the few cognitive domains failing to respond to CRT $(158,159)$. Considering the overlapping link between verbal memory and hippocampal volume, frontal and parietal lobe function in both disorders, it would be informative to investigate whether CRT affects structure and function of those regions.

\section{Targeting Social Cognition Deficits}

Bechi and colleagues (168) showed that combination of CRT and social cognitive or ToM training improved social cognitive abilities even further than CRT alone in people with schizophrenia (168). ToM training involves reading comic strips to be trained to recognize relevant details and collect and meaningful pieces of information such as place, time, characters' actions, and physical features. Another study revealed that adding to standard CRT computerized social cognition training such as the interactive guide to emotions that is designed to train patients to recognize emotions and other mental states, produced greater improvement not only in social cognition, but also other cognitive domains such as visual memory and executive function in people with schizophrenia (169). Evidence reviewed by Campos et al. (170) revealed that emotion recognition training leads to an increase in activation in the fronto-temporal-occipital regions, postcentral gyrus, right amygdala, medial $\mathrm{PFC}$, and right putamen in people with schizophrenia (170). Hyperactivity in those regions correlated with social cognition improvement, in particular medial PFC activation was associated with increased social functioning 6 months after treatment (170). Such evidence in schizophrenia suggests emotion recognition training as a strong candidate to improve social cognition in people with meth use disorder. However, interventions specifically targeting social cognition have not yet been studied in people with meth use disorder. Note that there is an opposite pattern of cingulate dysfunction underlying emotion regulation observed in people with schizophrenia and meth use disorder (Figure 2). It is possible that there is a dissociation between the two disorders in how emotion recognition training affects the cognitive deficits and the related hyperactivity in the cingulate cortex.

\section{Targeting Working Memory Deficits}

Evidence reviewed by Lett et al. (171) suggests that computerbased programs using auditory exercises aiming to improve the speed and accuracy of auditory information processing produce long-lasting improvement in verbal working memory in people with schizophrenia (171). This is in line with a recent meta-analysis specifically investigating computer-based drill and practice training (172). Prikken et al. (172) found that working memory was among the most improved domains, and noted that shorter, but more intense training programs yielded larger effect sizes (172). On the other hand, they found limited improvements in functional outcome (172), which suggests that computerized training programs should be used in conjunction with another line of CRT involving face-to-face training.

Consistent with schizophrenia research, a pilot study in people with meth use disorder found improvement in working memory following four weeks of increasingly difficult N-back memory task training, which was also linked to improved impulse control (164). In people with meth use disorder, it is promising that working memory training has been shown to normalize frontostriatal structure and function (163).

\section{SUMMARY}

Meth use disorder and schizophrenia are two distinct but often comorbid mental disorders. The present review highlights shared cognitive impairments and brain abnormalities in people with schizophrenia or meth use disorder, with the hope to gain insight from schizophrenia research to develop treatments for people with meth use disorder, which is a global problem with increasing health, social and economic burden (173). Their shared key features including deficits in learning, memory, social cognition, working memory and inhibitory control, and abnormal frontostriatal and insular cortex structure and function, all impact on treatment outcome and daily functioning. There is some evidence that these deficits and abnormalities may precede the development of the disorders. Targeted treatment of the cognitive deficits in a vulnerable population may improve brain and cognition, and prevent or delay the onset of the disorders. Such treatment approaches for meth use disorder can capitalize on the well-established literature on schizophrenia. Specifically CRTs have been shown to successfully improve cognitive impairments, normalize brain function, and increase treatment efficacy in people with schizophrenia, and these treatment approaches should be examined for their efficacy to improve similar impairments in people with meth use disorder. This is an urgent call to 
action because there is no FDA-approved pharmacotherapy to treat stimulant use disorders. Importantly, more research is needed to fully understand the mechanisms underlying CRT, with the aim to tailor CRT for each individual patient with different levels of cognitive and brain impairments that have been shown to affect treatment outcomes.

\section{AUTHOR CONTRIBUTIONS}

AG, SR, and JK contributed to the conception and design of the review. AG and JK conducted the review. AG wrote the initial version of the manuscript, with subsequent contribution from $\mathrm{YB}, \mathrm{AL}, \mathrm{BB}, \mathrm{EN}, \mathrm{SR}$, and JK. All authors contributed to and approved the submitted version.

\section{REFERENCES}

1. American Psychiatric Association. Diagnostic and Statistical Manual of Mental Disorders (DSM). Arlington, VA: American Psychiatric Publishing. Salem Press (2013). doi: 10.1176/appi.books. 9780890425596

2. United Nations Office on Drugs and Crime, World drug report 2010. United Nations Publication, Sales No. E.10.XI.13. (2010), 316. Joost. 2010.

3. United Nations Office on Drugs and Crime. Market analysis of synthetic drugs. Amphetamine-type stimulants, new psychoactive substances. World drug report 2017. United Nations publication, Sales No. E.17.XI.6. (2017), 60.

4. Center for Behavioral Health Statistics and Quality. Behavioral health trends in the United States: Results from the 2014 National Survey on Drug Use and Health (HHS Publication No. SMA 15-4927, NSDUH Series H-50). (2015), 64 .

5. Baker A, Lee NK. A review of psychosocial interventions for amphetamine use. Drug Alcohol Rev (2003) 22(3):323-35. doi: 10.1080/0959523031000154472

6. Luikinga SJ, Kim JH, Perry CJ. Developmental perspectives on methamphetamine abuse: Exploring adolescent vulnerabilities on brain and behavior. Prog Neuropsychopharmacol Biol Psychiatry (2017) 87:78-84. doi: 10.1016/j.pnpbp.2017.11.010

7. Wearne TA, Cornish JL. A Comparison of MethamphetamineInduced Psychosis and Schizophreniaa review of positive, negative, and cognitive symptomatology. Front Psychiatry (2018) 9:491. doi: 10.3389/ fpsyt.2018.00491

8. Polimanti R, Agrawal A, Gelernter J. Schizophrenia and substance use comorbidity: a genome-wide perspective. Genome Med (2017) 9(1):9-11. doi: 10.1186/s13073-017-0423-3

9. Hartz SM, Horton AC, Oehlert M, Carey CE, Agrawal A, Bogdan R, et al. Association between substance use disorder and polygenic liability to schizophrenia. Biol Psychiatry (2017) 82(10):709-15. doi: 10.1016/j. biopsych.2017.04.020

10. Gordon A. Comorbidity of mental disorders and substance use: a brief guide for the primary care clinician. Canberra: National Drug Strategy. (2009).

11. Kavanagh DJ, McGrath J, Saunders JB, Dore G, Clark D. Substance misuse in patients with schizophrenia. Drugs (2002) 62(5):743-55. doi: 10.2165/00003495-200262050-00003

12. Li H, Lu Q, Xiao E, Li Q, He Z, Mei X. Methamphetamine enhances the development of schizophrenia in first-degree relatives of patients with schizophrenia. Can J Psychiatry (2014) 59(2):107-13. doi: 10.1177/070674 371405900206

13. Kittirattanapaiboon P, Mahatnirunkul S, Booncharoen H, Thummawomg P, Dumrongchai U, Chutha W. Long-term outcomes in methamphetamine psychosis patients after first hospitalisation. Drug Alcohol Rev (2010) 29(4):456-61. doi: 10.1111/j.1465-3362.2010.00196.x

14. Archer T, Kostrzewa RM. Neuroteratology and Animal Modeling of Brain Disorders. In: Kostrzewa RM, Archer T, editors. Neurotoxin Modeling of Brain Disorders-Life-long Outcomes in Behavioral Teratology.

\section{FUNDING}

This research was supported by a Melbourne Research Scholarship from the University of Melbourne (AG); National Health and Medical Research Council (NHMRC) Principal Research Fellowship (AL); National Institutes of Health Grant P01DA008227 (EN); and NHMRC Career Development Fellowship (JK).

\section{ACKNOWLEDGMENTS}

We acknowledge the Victorian Government's Operational Infrastructure Support Program. We thank Tanya Maturi for the initial assistance with the literature search.

Switzerland, Cham: Springer International Publishing; (2016). p. 1-40. doi: 10.1007/7854_2015_434

15. Geyer MA, Krebs-Thomson K, Braff DL, Swerdlow NR. Pharmacological studies of prepulse inhibition models of sensorimotor gating deficits in schizophrenia: a decade in review. Psychopharmacol (Berl) (2001) 156(2):117-54. doi: 10.1007/s002130100811

16. Arai S, Takuma K, Mizoguchi H, Ibi D, Nagai T, Takahashi K, et al. Involvement of pallidotegmental neurons in methamphetamine- and MK-801-induced impairment of prepulse inhibition of the acoustic startle reflex in mice: Reversal by GABAB receptor agonist baclofen. Neuropsychopharmacology (2008) 33(13):3164-75. doi: 10.1038/npp.2008.41

17. Hadamitzky M, Markou A, Kuczenski R. Extended access to methamphetamine self-administration affects sensorimotor gating in rats. Behav Brain Res (2011) 217(2):386-90. doi: 10.1016/j.bbr.2010.11.009

18. Nakato Y, Abekawa T, Ito K, Inoue T, Koyama T. Lamotrigine blocks the initiation and expression of repeated high-dose methamphetamine-induced prepulse inhibition deficit in rats. Neurosci Lett (2010) 481(3):183-7. doi: 10.1016/j.neulet.2010.07.002

19. Dai H, Okuda H, Iwabuchi K, Sakurai E, Chen Z, Kato M, et al. Social isolation stress significantly enhanced the disruption of prepulse inhibition in mice repeatedly treated with methamphetamine. Ann N Y Acad Sci (2004) 1025:257-66. doi: 10.1196/annals.1316.032

20. Acevedo SF, De Esch IJP, Raber J. Sex- and histamine-dependent long-term cognitive effects of methamphetamine exposure. Neuropsychopharmacology (2007) 32(3):665-72. doi: 10.1038/sj.npp.1301091

21. Strauss L, Brink CB, Moller M, Stein DJ, Harvey BH. Late-life effects of chronic methamphetamine exposure during puberty on behaviour and corticostriatal mono-amines in social isolation-reared rats. Dev Neurosci (2014) 36(1):18-28. doi: 10.1159/000357495

22. Thompson PM, Hayashi KM, Simon SL, Geaga JA, Hong MS, Sui Y, et al. Structural abnormalities in the brains of human subjects who use methamphetamine. J Neurosci (2004) 24(26):6028-36. doi: 10.1523/ JNEUROSCI.0713-04.2004

23. Nestor LJ, Ghahremani DG, Monterosso J, London ED. Prefrontal hypoactivation during cognitive control in early abstinent methamphetaminedependent subjects. Psychiatry Res (2011) 194(3):287-95. doi: 10.1016/j. pscychresns.2011.04.010

24. Schwartz DL, Mitchell AD, Lahna DL, Luber HS, Huckans MS, Mitchell $\mathrm{SH}$, et al. Global and local morphometric differences in recently abstinent methamphetamine-dependent individuals. NeuroImage (2010) 50(4):1392401. doi: 10.1016/j.neuroimage.2010.01.056

25. Uhlmann A, Fouche JP, Lederer K, Meintjes EM, Wilson D, Stein DJ. White matter microstructure and impulsivity in methamphetamine dependence with and without a history of psychosis. Hum Brain Mapp (2016) 37(6):205567. doi: 10.1002/hbm.23159

26. Salo R, Fassbender C, Buonocore MH, Ursu S. Behavioral regulation in methamphetamine abusers: An fMRI study. Psychiatry Res - Neuroimaging (2013) 211(3):234-8. doi: 10.1016/j.pscychresns.2012.10.003 
27. Manoach DS. Prefrontal cortex dysfunction during working memory performance in schizophrenia: reconciling discrepant findings. Schizophr Res (2003) 60(2-3):285-98. doi: 10.1016/S0920-9964(02)00294-3

28. Minzenberg MJ, Laird AR, Thelen S, Carter CS, Glahn DC. Meta-analysis of 41 functional neuroimaging studies of executive function in schizophrenia. Arch Gen Psychiatry (2009) 66(8):811-22. doi: 10.1001/archgenpsychiatry.2009.91

29. Chen XJ, Wang Y, Wang Y, Yang TX, Zou LQ, Huang J, et al. Neural correlates of prospective memory impairments in schizophrenia. Neuropsychology (2016) 30(2):169-80. doi: 10.1037/neu0000225

30. Krystal JH, D'Souza DC, Madonick S, Petrakis IL. Toward a rational pharmacotherapy of comorbid substance abuse in schizophrenic patients. Schizophr Res (1999) 35:S35-49. doi: 10.1016/S0920-9964(98)00162-5

31. Weber E, Blackstone K, Iudicello JE, Morgan EE, Grant I, Moore DJ, et al. Neurocognitive deficits are associated with unemployment in chronic methamphetamine users. Drug Alcohol Depend (2012) 125(1-2):146-53. doi: 10.1016/j.drugalcdep.2012.04.002

32. Zhong $\mathrm{N}$, Jiang $\mathrm{H}, \mathrm{Du}$ J, Zhao $\mathrm{Y}$, Sun $\mathrm{H}, \mathrm{Xu} \mathrm{D}$, et al. The cognitive impairments and psychological wellbeing of methamphetamine dependent patients compared with health controls. Prog Neuropsychopharmacol Biol Psychiatry (2016) 69:31-7. doi: 10.1016/j.pnpbp.2016.04.005

33. Green MF, Kern RS, Heaton RK. Longitudinal studies of cognition and functional outcome in schizophrenia: implications for MATRICS. Schizophr Res (2004) 72(1):41-51. doi: 10.1016/j.schres.2004.09.009

34. Dean AC, Sevak RJ, Monterosso JR, Hellemann G, Sugar CA, London ED. Acute modafinil effects on attention and inhibitory control in methamphetamine-dependent humans. J Stud Alcohol Drugs (2011) 72(6):943-53. doi: 10.15288/jsad.2011.72.943

35. Lyoo IK, Yoon S, TS K, SM L, Choi Y, JE K, et al. Predisposition to and effects of methamphetamine use on the adolescent brain. Mol Psychiatry (2015) 20(12):1516-24. doi: 10.1038/mp.2014.191

36. Mahoney JJ, Thompson-Lake DGY, Cooper K, Verrico CD, Newton TF, De La Garza R. A comparison of impulsivity, depressive symptoms, lifetime stress and sensation seeking in healthy controls versus participants with cocaine or methamphetamine use disorders. J Psychopharmacol (2015) 29(1):50-6. doi: 10.1177/0269881114560182

37. Kim JE, Kim GH, Hwang J, Kim JY, Renshaw PF, Yurgelun-Todd DA, et al. Metabolic alterations in the anterior cingulate cortex and related cognitive deficits in late adolescent methamphetamine users. Addict Biol (2016) 23:327-336. doi: 10.1111/adb.12473

38. Andres T, Ernst T, Oishi K, Greenstein D, Nakama H, Chang L. Brain Microstructure and impulsivity differ between current and past methamphetamine users. J Neuroimmune Pharmacol (2016) 11(3):531-41. doi: 10.1007/s11481-016-9675-8

39. Su H, Tao J, Zhang J, Xie Y, Wang Y, Zhang Y, et al. The effects of BDNF Val66Met gene polymorphism on serum BDNF and cognitive function in methamphetamine-dependent patients and normal controls: a casecontrol study. J Clin Psychopharmacol (2015) 35(5):517-24. doi: 10.1097/ JCP.0000000000000390

40. Simon SL, Domier C, Carnell J, Brethen P, Rawson R, Ling W, et al. Cognitive impairment in individuals currently using methamphetamine. Am J Addict (2000) 9(3):222-31. doi: 10.1080/10550490050148053

41. Simon SL, Domier CP, Sim T, Richardson K, Rawson RA, Ling W. Cognitive performance of current methamphetamine and cocaine abusers. J Addict Dis (2002) 21(1):61-74. doi: 10.1300/J069v21n01_06

42. Monterosso JR, Aron AR, Cordova X, Xu J, London ED. Deficits in response inhibition associated with chronic methamphetamine abuse. Drug Alcohol Depend (2005) 79(2):273-7. doi: 10.1016/j.drugalcdep.2005.02.002

43. Iudicello JE, Woods SP, Vigil O, Scott JC, Cherner M, Heaton RK, et al. Longer term improvement in neurocognitive functioning and affective distress among methamphetamine users who achieve stable abstinence. J Clin Exp Neuropsychol (2010) 32(7):704-18. doi: 10.1080/13803390903512637

44. Simon SL, Dean AC, Cordova X, Monterosso JR, London ED. Methamphetamine dependence and neuropsychological functioning: evaluating change during early abstinence. J Stud Alcohol Drugs (2010) 71(3):335-44. doi: 10.15288/jsad.2010.71.335

45. Kalechstein AD, Newton TF, Green M. Methamphetamine dependence is associated with neurocognitive impairment in the initial phases of abstinence. J Neuropsychiatry Clin Neurosci (2003) 15(2):215-20. doi: 10.1176/jnp.15.2.215

46. Hoffman WF, Moore M, Templin R, McFarland B, Hitzemann RJ, Mitchell SH. Neuropsychological function and delay discounting in methamphetaminedependent individuals. Psychopharmacol (Berl) (2006) 188(2):162-70. doi: 10.1007/s00213-006-0494-0

47. Woods SP, Rippeth JD, Conover E, Gongvatana A, Gonzalez R, Carey CL, et al. Deficient strategic control of verbal encoding and retrieval in individuals with methamphetamine dependence. Neuropsychology (2005) 19(1):35-43. doi: 10.1037/0894-4105.19.1.35

48. Van Der Plas EAA, Van Den Wildenberg WPM, Tranel D, Bechara A. Executive control deficits in substance-dependent individuals: a comparison of alcohol, cocaine, and methamphetamine and of men and women. J Clin Exp Neuropsychol (2009) 31(6):706-19. doi: 10.1080/13803390802484797

49. Boileau I, Rusjan P, Houle S, Wilkins D, Tong J, Selby P, et al. Increased vesicular monoamine transporter binding during early abstinence In human methamphetamine users: is VMAT2 a stable dopamine neuron biomarker? J Neurosci (2008) 28(39):9850-6. doi: 10.1523/JNEUROSCI.3008-08.2008

50. Kim YT, Kwon DH, Chang Y. Impairments of facial emotion recognition and theory of mind in methamphetamine abusers. Psychiatry Res (2011) 186(1):80-4. doi: 10.1016/j.psychres.2010.06.027

51. Uhlmann A, Ipser JC, Wilson D, Stein DJ. Social cognition and aggression in methamphetamine dependence with and without a history of psychosis. Metab Brain Dis (2018) 33(2):559-68. doi: 10.1007/s11011-017-0157-3

52. Salo R, Ravizza S, Fassbender C. Overlapping cognitive patterns in schizophrenia and methamphetamine dependence. Cognit Behav Neurol (2011) 24(4):187-93. doi: 10.1097/WNN.0b013e31823fc1d0

53. Gonzalez R, Bechara A, Martin EM. Executive functions among individuals with methamphetamine or alcohol as drugs of choice: preliminary observations. J Clin Exp Neuropsychol (2007) 29(2):155-9. doi: $10.1080 / 13803390600582446$

54. Morgan EE, Woods SP, Poquette AJ, Vigil O, Heaton RK, Grant I. Visual memory in methamphetamine-dependent individuals: Deficient strategic control of encoding and retrieval. Aust N Z J Psychiatry (2012) 46(2):141-52. doi: $10.1177 / 0004867411433212$

55. Salo R, Nordahl TE, Possin K, Leamon M, Gibson DR, Galloway GP, et al. Preliminary evidence of reduced cognitive inhibition in methamphetaminedependent individuals. Psychiatry Res (2002) 111(1):65-74. doi: 10.1016/ S0165-1781(02)00111-7

56. Salo R, Ursu S, Buonocore $\mathrm{MH}$, Leamon $\mathrm{MH}$, Carter C. Impaired prefrontal cortical function and disrupted adaptive cognitive control in methamphetamine abusers: a functional magnetic resonance imaging study. Biol Psychiatry (2009) 65(8):706-9. doi: 10.1016/j.biopsych.2008.11.026

57. Kim SJ, Lyoo IK, Hwang J, Chung A, Young HS, Kim J, et al. Prefrontal greymatter changes in short-term and long-term abstinent methamphetamine abusers. Int J Neuropsychopharmacol (2006) 9(2):221-8. doi: 10.1017/ S1461145705005699

58. Rendell PG, Mazur M, Henry JD. Prospective memory impairment in former users of methamphetamine. Psychopharmacol (Berl) (2009) 203(3):609-16. doi: 10.1007/s00213-008-1408-0

59. Henry JD, Mazur M, Rendell PG. Social-cognitive difficulties in former users of methamphetamine. Br J Clin Psychol (2009) 48(3):323-7. doi: 10.1111/ j.2044-8260.2009.tb00487.x

60. Johanson CE, Frey KA, Lundahl LH, Keenan P, Lockhart N, Roll J, et al. Cognitive function and nigrostriatal markers in abstinent methamphetamine abusers. Psychopharmacol (Berl) (2006) 185(3):327-38. doi: 10.1007/ s00213-006-0330-6

61. Iudicello JE, Weber E, Grant I, Weinborn M, Woods SP, Atkinson JH, et al. Misremembering future intentions in methamphetamine-dependent individuals. Clin Neuropsychol (2011) 25(2):269-86. doi: 10.1080/13854046.2 010.546812

62. Cherner M, Suarez P, Casey C, Deiss R, Letendre S, Marcotte T, et al. Methamphetamine use parameters do not predict neuropsychological impairment in currently abstinent dependent adults. Drug Alcohol Depend (2010) 106(2-3):154-63. doi: 10.1016/j.drugalcdep.2009.08.010

63. Rippeth JD, Heaton RK, Carey CL, Marcotte TD, Moore DJ, Gonzalez R, et al. Methamphetamine dependence increases risk of neuropsychological 
impairment in HIV infected persons. J Int Neuropsychol Soc (2004) 10(1):114. doi: $10.1017 /$ S1355617704101021

64. Chang L, Ernst T, Speck O, Patel H, DeSilva M, Leonido-Yee M, et al. Perfusion MRI and computerized cognitive test abnormalities in abstinent methamphetamine users. Psychiatry Res (2002) 114(2):65-79. doi: 10.1016/ S0925-4927(02)00004-5

65. King G, Alicata D, Cloak C, Chang L. Neuropsychological deficits in adolescent methamphetamine abusers. Psychopharmacol (Berl) (2010) 212(2):243-9. doi: 10.1007/s00213-010-1949-x

66. Stock AK, Rädle M, Beste C, Master ZR, Malek NI. Methamphetamineassociated difficulties in cognitive control allocation may normalize after prolonged abstinence. Prog Neuropsychopharmacol Biol Psychiatry (2018) 88:41-52. doi: 10.1016/j.pnpbp.2018.06.015

67. Gonzalez R, Rippeth JD, Carey CL, Heaton RK, Moore DJ, Schweinsburg BC, et al. Neurocognitive performance of methamphetamine users discordant for history of marijuana exposure. Drug Alcohol Depend (2004) 76(2):18190. doi: 10.1016/j.drugalcdep.2004.04.014

68. Salo R, Nordahl TE, Natsuaki Y, Leamon MH, Galloway GP, Waters C, et al. Attentional control and brain metabolite levels in methamphetamine abusers. Biol Psychiatry (2007) 61(11):1272-80. doi: 10.1016/j.biopsych.2006.07.031

69. Salo R, Nordahl TE, Galloway GP, Moore CD, Waters C, Leamon MH. Drug abstinence and cognitive control in methamphetamine-dependent individuals. J Subst Abuse Treat (2009) 37(3):292-7. doi: 10.1016/j.jsat. 2009.03.004

70. Moon M, Do KS, Park J, Kim D. Memory impairment in methamphetamine dependent patients. Int J Neurosci (2007) 117(1):1-9. doi: 10.1080/0020745 0500535503

71. Cruickshank CC, Dyer KR. A review of the clinical pharmacology of methamphetamine. Addiction (2009) 104(7):1085-99. doi: 10.1111/j.13600443.2009.02564.x

72. Riddle EL, Fleckenstein AE, Hanson GR. Role of monoamine transporters in mediating psychostimulant effects. Drug Addict From Basic Res to Ther (2008) 7(4):169-77. doi: 10.1007/978-0-387-76678-2_11

73. Sulzer D, Sonders MS, Poulsen NW, Galli A. Mechanisms of neurotransmitter release by amphetamines: a review. Prog Neurobiol (2005) 75(6):406-33. doi: 10.1016/j.pneurobio.2005.04.003

74. Kalivas PW, Volkow ND. The neural basis of addiction: A pathology of motivation and choice. Am J Psychiatry (2005) 162:1403-13. doi: 10.1176/ appi.ajp.162.8.1403

75. Howes OD, Kapur S. The dopamine hypothesis of schizophrenia: Version III - The final common pathway. Schizophr Bull (2009) 35(3):549-62. doi: 10.1093/schbul/sbp006

76. Potvin S, Pelletier J, Grot S, Hébert C, Barr A, Lecomte T. Cognitive deficits in individuals with methamphetamine use disorder: A meta-analysis. Addict Behav (2018) 80:154-60. doi: 10.1016/j.addbeh.2018.01.021

77. Heaton RK, Gladsjo JA, Palmer BW, Kuck J, Marcotte TD, Jeste DV. Stability and course of neuropsychological deficits in schizophrenia. Arch Gen Psychiatry (2001) 58(1):24-32. doi: 10.1001/archpsyc.58.1.24

78. Grimes KM, Zanjani A, Zakzanis KK. Memory impairment and the mediating role of task difficulty in patients with schizophrenia. Psychiatry Clin Neurosci (2017) 71:600-11. doi: 10.1111/pcn.12520

79. Ordemann GJ, Opper J, Davalos D. Prospective memory in schizophrenia: a review. Schizophr Res (2014) 155(1):77-89. doi: 10.1016/j.schres.2014.03.008

80. Wang Y, Chan RCK, Shum DHK. Schizophrenia and prospective memory impairments: a review. Clin Neuropsychol (2017) 32(5):836-57. doi: 10.1080/13854046.2017.1406144

81. Raskin SA, Maye J, Rogers A, Correll D, Zamroziewicz M, Kurtz M. Prospective memory in schizophrenia: relationship to medication management skills, neurocognition, and symptoms in individuals with schizophrenia. Neuropsychology (2014) 28(3):359-65. doi: 10.1037/neu0000040

82. Reichel CM, Schwendt M, McGinty JF, Olive MF, See RE. Loss of object recognition memory produced by extended access to methamphetamine selfadministration is reversed by positive allosteric modulation of metabotropic glutamate receptor 5. Neuropsychopharmacology (2011) 36(4):782-92. doi: 10.1038/npp.2010.212

83. ReichelCM,RamseyLA,SchwendtM,McGintyJF,SeeRE.Methamphetamineinduced changes in the object recognition memory circuit. Neuropharmacol (2012) 62(2):1119-26. doi: 10.1016/j.neuropharm.2011.11.003
84. Melo P, Magalhães A, Alves CJ, Tavares MA, de Sousa L, Summavielle T, et al. Methamphetamine mimics the neurochemical profile of aging in rats and impairs recognition memory. Neurotoxicology (2012) 33(3):491-9. doi: 10.1016/j.neuro.2012.03.002

85. Luikinga SJ, Perry CJ, Madsen HB, Lawrence AJ, Kim JH. Effects of methamphetamine exposure on fear learning and memory in adult and adolescent rats. Neurochem Res (2019) (0123456789):2081-91. doi: 10.1007/ s11064-019-02845-x

86. Recinto P, Samant ARH, Chavez G, Kim A, Yuan CJ, Soleiman M, et al. Levels of neural progenitors in the hippocampus predict memory impairment and relapse to drug seeking as a function of excessive methamphetamine self-administration. Neuropsychopharmacology (2012) 37(5):1275-87. doi: 10.1038/npp.2011.315

87. Kesby JP, Markou A, Semenova S. Cognitive deficits associated with combined HIV gp120 expression and chronic methamphetamine exposure in mice. Eur Neuropsychopharmacol (2015) 25(1):141-50. doi: 10.1016/j. euroneuro.2014.07.014

88. Chen YJ, Liu YL, Zhong Q, Yu YF, Su HL, Toque HA, etal. Tetrahydropalmatine protects against methamphetamine-induced spatial learning and memory impairment in mice. Neurosci Bull (2012) 28(3):222-32. doi: 10.1007/ s12264-012-1236-4

89. North A, Swant J, Salvatore MF, Gamble-George J, Prins P, Butler B, et al. Chronic methamphetamine exposure produces a delayed, long-lasting memory deficit. Synapse (2013) 67(5):245-57. doi: 10.1002/syn.21635

90. Kesby JP, Fields JA, Chang A, Coban H, Achim CL, Semenova S. Effects of HIV-1 TAT protein and methamphetamine exposure on visual discrimination and executive function in mice. Behav Brain Res (2018) 349:73-9. doi: 10.1016/j.bbr.2018.04.046

91. Preston AR, Eichenbaum H. Interplay of hippocampus and prefrontal cortex in memory. Curr Biol (2013) 23(17):R764-73. doi: 10.1016/j.cub. 2013.05.041

92. Du J, Quan M, Zhuang W, Zhong N, Jiang H, Kennedy DN, et al. Hippocampal volume reduction in female but not male recent abstinent methamphetamine users. Behav Brain Res (2015) 289:78-83. doi: 10.1016/j. bbr.2015.04.033

93. Antoniades M, Schoeler T, Radua J, Valli I, Allen P, Kempton MJ, et al. Verbal learning and hippocampal dysfunction in schizophrenia: A meta-analysis. Neurosci Biobehav Rev (2018) 86:166-75. doi: 10.1016/j.neubiorev.2017.12.001

94. Burgess PW, Gonen-Yaacovi G, Volle E. Functional neuroimaging studies of prospective memory: What have we learnt so far? Neuropsychol (2011) 49(8):2246-57. doi: 10.1016/j.neuropsychologia.2011.02.014

95. Chan RCK, Di X, McAlonan GM, Gong Q. Brain anatomical abnormalities in high-risk individuals, first-episode, and chronic schizophrenia: an activation likelihood estimation meta-analysis of illness progression. Schizophr Bull (2011) 37(1):177-88. doi: 10.1093/schbul/sbp073

96. Glahn DC, Laird AR, Ellison-Wright I, Thelen SM, Robinson JL, Lancaster JL, et al. Meta-analysis of gray matter anomalies in schizophrenia: application of anatomic likelihood estimation and network analysis. Biol Psychiatry (2008) 64(9):774-81. doi: 10.1016/j.biopsych.2008.03.031

97. Savla GN, Vella L, Armstrong CC, Penn DL, Twamley EW. Deficits in domains of social cognition in schizophrenia: A meta-analysis of the empirical evidence. Schizophr Bull (2013) 39(5):979-92. doi: 10.1093/schbul/sbs080

98. Pinkham AE. Social cognition in schizophrenia Vol. 75. J Clin Psychiatry, Wellington (2014) p. 14-9. doi: 10.4088/JCP.13065su1.04

99. Manning EE, van den Buuse M. Altered social cognition in male BDNF heterozygous mice and following chronic methamphetamine exposure. Behav Brain Res (2016) 305:181-5. doi: 10.1016/j.bbr.2016.03.014

100. Couture SM, Penn DL, Roberts DL. The functional significance of social Cognition in Schizophrenia: a review. Schizophr Bull (2006) 32:S44-63. doi: $10.1093 / \mathrm{schbul} / \mathrm{sbl} 029$

101. Javed A, Charles A. The importance of social cognition in improving functional outcomes in schizophrenia. Front Psychiatry (2018) 9:1-14. doi: $10.3389 /$ fpsyt.2018.00157

102. Gasquoine PG. Contributions of the insula to cognition and emotion. Neuropsychol Rev (2014) 24(4):77-87. doi: 10.1007/s11065-014-9246-9

103. Davidson RJ, Putnam KM, Larson CL. Dysfunction in the neural circuitry of emotion regulation-a possible prelude to violence. Science (2000) 289(5479):591-4. doi: 10.1126/science.289.5479.591 
104. Gallagher HL, Frith CD. Functional imaging oftheory of mind. Trends Cognit Sci (2003) 7(2):77-83. doi: 10.1016/S1364-6613(02)00025-6

105. Kim YT, Song HJ, Seo JH, Lee JJ, Lee J, Kwon DH, et al. The differences in neural network activity between methamphetamine abusers and healthy subjects performing an emotion-matching task: Functional MRI study. NMR BioMed (2011) 24(10):1392-400. doi: 10.1002/nbm.1702

106. Payer DE, Lieberman MD, Monterosso JR, Xu J, Fong TW, London ED. Differences in cortical activity between methamphetamine-dependent and healthy individuals performing a facial affect matching task. Drug Alcohol Depend (2008) 93(1-2):93-102. doi: 10.1016/j.drugalcdep.2007.09.009

107. Vercammen A, Morris R, Green MJ, Lenroot R, Kulkarni J, Carr VJ, et al. Reduced neural activity of the prefrontal cognitive control circuitry during response inhibition to negative words in people with schizophrenia. J Psychiatry Neurosci (2012) 37(6):379-88. doi: 10.1503/jpn.110088

108. Szabó ÁG, Farkas K, Marosi C, Kozák LR, Rudas G, Réthelyi J, et al. Impaired mixed emotion processing in the right ventrolateral prefrontal cortex in schizophrenia: an fMRI study. BMC Psychiatry (2017) 17(1):391. doi: 10.1186/s12888-017-1558-x

109. Sprengelmeyer R, Rausch M, Eysel UT, Przuntek H. Neural structures associated with recognition of facial expressions of basic emotions. Proc Biol Sci (1998) 265(1409):1927-31. doi: 10.1098/rspb.1998.0522

110. Li HJ, Chan RCK, Gong QY, Liu Y, Liu SM, Shum D, et al. Facial emotion processing in patients with schizophrenia and their non-psychotic siblings: A functional magnetic resonance imaging study. Schizophr Res (2012) 134(2-3):143-50. doi: 10.1016/j.schres.2011.10.019

111. Park HY, Yun JY, Shin NY, Kim SY, Jung WH, Shin YS, et al. Decreased neural response for facial emotion processing in subjects with high genetic load for schizophrenia. Prog Neuropsychopharmacol Biol Psychiatry (2016) 71:90-6. doi: 10.1016/j.pnpbp.2016.06.014

112. Phillips ML, Williams L, Senior C, Bullmore ET, Brammer MJ, Andrew C, et al. A differential neural response to threatening and non-threatening negative facial expressions in paranoid and non-paranoid schizophrenics. Psychiatry Res - Neuroimaging (1999) 92(1):11-31. doi: 10.1016/S0925-4927(99)00031-1

113. Seiferth NY, Pauly K, Kellermann T, Shah NJ, Ott G, Herpertz-Dahlmann B, et al. Neuronal correlates of facial emotion discrimination in early onset schizophrenia. Neuropsychopharmacology (2009) 34(2):477-87. doi: 10.1038/npp.2008.93

114. Nakama H, Chang L, Fein G, Shimotsu R, Jiang CS, Ernst T. Methamphetamine users show greater than normal age-related cortical gray matter loss. Addiction (2011) 106(8):1474-83. doi: 10.1111/j.1360-0443.2011.03433.x

115. Morales AM, Lee B, Hellemann G, O'Neill J, London ED. Gray-matter volume in methamphetamine dependence: cigarette smoking and changes with abstinence from methamphetamine. Drug Alcohol Depend (2012) 125(3):230-8. doi: 10.1016/j.drugalcdep.2012.02.017

116. Ellison-Wright I, Glahn DC, Laird AR, Thelen SM, Bullmore E. The anatomy of first-episode and chronic schizophrenia: an anatomical likelihood estimation meta-analysis. Am J Psychiatry (2008) 165(8):1015-23. doi: 10.1176/appi.ajp. 2008.07101562

117. Shepherd AM, Matheson SL, Laurens KR, Carr VJ, Green MJ. Systematic meta-analysis of insula volume in schizophrenia. Biol Psychiatry (2012) 72(9):775-84. doi: 10.1016/j.biopsych.2012.04.020

118. Jáni $M$, Kašpárek T. Emotion recognition and theory of mind in schizophrenia: A meta-analysis of neuroimaging studies. World J Biol Psychiatry (2017) 19(S3):1-11. doi: 10.1080/15622975.2017.1324176

119. Diamond A. Executive functions. Annu Rev Clin Psychol (2014) 64:135-68. doi: 10.1146/annurev-psych-113011-143750

120. Nuechterlein KH, Barch DM, Gold JM, Goldberg TE, Green MF, Heaton RK. Identification of separable cognitive factors in schizophrenia. Schizophr Res (2004) 72(1):29-39. doi: 10.1016/j.schres.2004.09.007

121. Silver H, Feldman P, Bilker W, Gur RC. Working memory deficit as a core neuropsychological dysfunction in schizophrenia. Am J Psychiatry (2003) 160(10):1809-16. doi: 10.1176/appi.ajp.160.10.1809

122. Laurenson C, Gorwood P, Orsat M, Lhuillier JP, Le Gall D, Richard-Devantoy S. Cognitive control and schizophrenia: the greatest reliability of the stroop task. Psychiatry Res (2015) 227(1):10-6. doi: 10.1016/j.psychres.2015.03.004

123. Westerhausen R, Kompus K, Hugdahl K. Impaired cognitive inhibition in schizophrenia: a meta-analysis of the Stroop interference effect Vol. 133. Schizophrenia Research: Netherlands; (2011) p. 172-81. doi: 10.1016/j. schres.2011.08.025
124. Reichenberg A, Caspi A, Harrington H, Houts R, Keefe RSE, Murray RM, et al. Static and dynamic cognitive deficits in childhood preceding adult schizophrenia: a 30-year study. Am J Psychiatry (2010) 167(2):160-9. doi: 10.1176/appi.ajp.2009.09040574

125. Istin M, Thiriet N, Solinas M. Behavioral flexibility predicts increased ability to resist excessive methamphetamine self-administration. Addict Biol (2017) 22(4):958-66. doi: 10.1111/adb.12384

126. Nagai T, Takuma K, Dohniwa M, Ibi D, Mizoguchi H, Kamei H, et al. Repeated methamphetamine treatment impairs spatial working memory in rats: Reversal by clozapine but not haloperidol. Psychopharmacol (Berl) (2007) 194(1):21-32. doi: 10.1007/s00213-007-0820-1

127. Mizoguchi H, Ibi D, Takase F, Nagai T, Kamei H, Toth E, et al. Nicotine ameliorates impairment of working memory in methamphetaminetreated rats. Behav Brain Res (2011) 220(1):159-63. doi: 10.1016/j.bbr. 2011.01.036

128. Lencz T, Smith CW, McLaughlin D, Auther A, Nakayama E, Hovey L, et al. Generalized and specific neurocognitive deficits in prodromal schizophrenia. Biol Psychiatry (2006) 59(9):863-71. doi: 10.1016/j.biopsych.2005.09.005

129. Logan GD, Schachar RJ, Tannock R. Impulsivity and inhibitory control. Psychol Sci (1997) Jan 18(1):60-4. doi: 10.1111/j.1467-9280.1997.tb00545.x

130. Heerey EA, Robinson BM, McMahon RP, Gold JM. Delay discounting in schizophrenia. Cognit Neuropsychiatry (2007) 12(3):213-21. doi: 10.1080/13546800601005900

131. Hoffman WF, Schwartz DL, Huckans MS, McFarland BH, Meiri G, Stevens AA, et al. Cortical activation during delay discounting in abstinent methamphetamine dependent individuals. Psychopharmacol (Berl) (2008) 201(2):183-93. doi: 10.1007/s00213-008-1261-1

132. Everitt BJ. Neural and psychological mechanisms underlying compulsive drug seeking habits and drug memories - indications for novel treatments of addiction. Eur J Neurosci (2014) 40(1):2163-82. doi: 10.1111/ejn.12644

133. Winhusen T, Lewis D, Adinoff B, Brigham G, Kropp F, Donovan DM, et al. Impulsivity is associated with treatment non-completion in cocaine- and methamphetamine-dependent patients but differs in nature as a function of stimulant-dependence diagnosis. J Subst Abuse Treat (2013) 44(5):541-7. doi: 10.1016/j.jsat.2012.12.005

134. Pattij T, De Vries TJ. The role of impulsivity in relapse vulnerability. Curr Opin Neurobiol (2013) 23(4):700-5. doi: 10.1016/j.conb.2013.01.023

135. Kiwanuka JN, Strauss GP, McMahon RP, Gold JM. Psychological predictors of functional outcome in people with schizophrenia. Schizophr Res (2014) 157(1-3):299-304. doi: 10.1016/j.schres.2014.04.030

136. Green MF. Cognitive impairment and functional outcome in schizophrenia and bipolar disorder. J Clin Psychiatry (2006) 67:3-8. doi: 10.4088/ JCP.1006e12

137. Guo X, Li J, Wang J, Fan X, Hu M, Shen Y, et al. Hippocampal and orbital inferior frontal gray matter volume abnormalities and cognitive deficit in treatment-naive, first-episode patients with schizophrenia. Schizophr Res (2014) 152(2-3):339-43. doi: 10.1016/j.schres.2013.12.015

138. Lederer K, Fouche JP, Wilson D, Stein DJ, Uhlmann A. Frontal white matter changes and aggression in methamphetamine dependence. Metab Brain Dis (2016) 31(1):53-62. doi: 10.1007/s11011-015-9775-9

139. Tobias MC, O'Neill J, Hudkins M, Bartzokis G, Dean AC, London ED. White-matter abnormalities in brain during early abstinence from methamphetamine abuse. Psychopharmacol (Berl) (2010) 209(1):13-24. doi: 10.1007/s00213-009-1761-7

140. Kim IS, Kim YT, Song HJ, Lee JJ, Kwon DH, Lee HJ, et al. Reduced corpus callosum white matter microstructural integrity revealed by diffusion tensor eigenvalues in abstinent methamphetamine addicts. Neurotoxicology (2009) 30(2):209-13. doi: 10.1016/j.neuro.2008.12.002

141. Salo R, Nordahl TE, Buonocore MH, Natsuaki Y, Waters C, Moore CD, et al. Cognitive control and white matter callosal microstructure in methamphetamine-dependent subjects: a diffusion tensor imaging study. Biol Psychiatry (2009) 65(2):122-8. doi: 10.1016/j.biopsych.2008.08.004

142. Edward M, Ross W, James P, Therese P. Stop-signal response inhibition in schizophrenia: behavioural, event-related potential and functional neuroimaging data. Biol Psychol (2012) 89(1):220-31. doi: 10.1016/j. biopsycho.2011.10.013

143. Fryer SL, Roach BJ, Ford JM, Donaldson KR, Calhoun VD, Pearlson GD, et al. Should I stay or should I go? FMRI study of response inhibition in early 
illness Schizophrenia and risk for psychosis. Schizophr Bull (2018) 45(1):111. doi: $10.1093 /$ schbul/sbx198

144. Bates TE, Strangward M, Keelan J, Davey GP, Munro PM, Clark JB. Inhibition of $\mathrm{N}$-acetylaspartate production: implications for 1H MRS studies in vivo. Neuroreport (1996) 7(8):1397-400. doi: 10.1097/00001756-199605310-00014

145. Howells FM, Uhlmann A, Temmingh H, Sinclair H, Meintjes E, Wilson D, et al. 1H-magnetic resonance spectroscopy (1H-MRS) in methamphetamine dependence and methamphetamine induced psychosis. Schizophr Res (2014) 153(1-3):122-8. doi: 10.1016/j.schres.2014.01.029

146. Kraguljac NV, Reid M, White D, Jones R, den Hollander J, Lowman D, et al. Neurometabolites in schizophrenia and bipolar disorder - A systematic review and meta-analysis. Psychiatry Res - Neuroimaging (2012) 203(2-3):111-25. doi: 10.1016/j.pscychresns.2012.02.003

147. Malaspina D, Kranz TM, Heguy A, Harroch S, Mazgaj R, Rothman K, et al. Prefrontal neuronal integrity predicts symptoms and cognition in schizophrenia and is sensitive to genetic heterogeneity. Schizophr Res (2016) 172(1-3):94-100. doi: 10.1016/j.schres.2016.02.031

148. Jessen F, Fingerhut N, Sprinkart AM, Kühn KU, Petrovsky N, Maier W, et al. $\mathrm{N}$-acetylaspartylglutamate (NAAG) and $\mathrm{N}$-acetylaspartate (NAA) in patients with schizophrenia. Schizophr Bull (2013) 39(1):197-205. doi: $10.1093 / \mathrm{schbul} / \mathrm{sbr} 127$

149. Reid MA, Salibi N, White DM, Gawne TJ, Denney TS, Lahti AC. 7T Proton Magnetic resonance spectroscopy of the anterior cingulate cortex in firstepisode schizophrenia. Schizophr Bull (2018) 45(1):1-10. doi: 10.1093/ schbul $/$ sbx 190

150. Delamillieure P, Constans J-M, Fernandez J, Brazo P, Dollfus S. Relationship between performance on the Stroop test and $\mathrm{N}$-acetylaspartate in the medial prefrontal cortex in deficit and nondeficit schizophrenia: preliminary results. Psychiatry Res (2004) 132(1):87-9. doi: 10.1016/j. pscychresns.2004.06.006

151. Mazgaj R, Tal A, Goetz R, Lazar M, Rothman K, Messinger JW, et al. Hypometabolism of the rostral anterior cingulate cortex associated with working memory impairment in 18 cases of schizophrenia. Brain Imaging Behav (2016) 10(1):115-23. doi: 10.1007/s11682-015-9372-x

152. Tandon N, Bolo NR, Sanghavi K, Mathew IT, Francis AN, Stanley JA, et al. Brain metabolite alterations in young adults at familial high risk for schizophrenia using proton magnetic resonance spectroscopy. Schizophr Res (2013) 148(1-3):59-66. doi: 10.1016/j.schres.2013.05.024

153. McKetin R, Baker AL, Dawe S, Voce A, Lubman DI. Differences in the symptom profile of methamphetamine-related psychosis and primary psychotic disorders. Psychiatry Res (2017) 251:349-54. doi: 10.1016/j. psychres.2017.02.028

154. Choi KH, Til W, Kurtz MM. Adjunctive pharmacotherapy for cognitive deficits in schizophrenia: Meta-analytical investigation of efficacy. $\mathrm{Br} \mathrm{J}$ Psychiatry (2013) 203(3):172-8. doi: 10.1192/bjp.bp.111.107359

155. Vingerhoets WAM, Bloemen OJN, Bakker G, van Amelsvoort TAMJ. Pharmacological interventions for the MATRICS cognitive domains in schizophrenia: What's the evidence. Front Psychiatry (2013) 4:1-22. doi: $10.3389 /$ fpsyt.2013.00157

156. Keefe RSE, Bilder RM, Davis SM, Harvey PD, Palmer BW, Gold JM, et al. Neurocognitive effects of antipsychotic medications in patients with chronic schizophrenia in the CATIE Trial. Arch Gen Psychiatry (2007) 64(6):631-2. doi: 10.1001/archpsyc.64.6.631

157. Iimori T, Nakajima S, Miyazaki T, Tarumi R, Ogyu K, Wada M, et al. Effectiveness of the prefrontal repetitive transcranial magnetic stimulation on cognitive profiles in depression, schizophrenia, and Alzheimer's disease: a systematic review. Prog Neuropsychopharmacol Biol Psychiatry (2019) 88:31-40. doi: 10.1016/j.pnpbp.2018.06.014

158. Wykes T, Huddy V, Cellard C, McGurk SR, Czobor P. A meta-analysis of cognitive remediation for schizophrenia: methodology and effect sizes. Am J Psychiatry (2011) 168(5):472-85. doi: 10.1176/appi.ajp.2010.10060855

159. McGurk SR, Twamley EW, Sitzer DI, McHugo GJ. Mueser KT. A metaanalysis of cognitive remediation in schizophrenia. Am J Psychiatry (2007) 164(12):1791-802. doi: 10.1176/appi.ajp.2007.07060906

160. Bryce S, Warren N, Ponsford J, Rossell S, Lee S. Understanding the lived experience of cognitive remediation in schizophrenia: a qualitative comparison with an active control. Psychiatr Rehabil J (2018) 41(4):302-11. doi: $10.1037 /$ prj0000309

161. Contreras NA, Lee S, Tan EJ, Castle DJ, Rossell SL. How is cognitive remediation training perceived by people with schizophrenia? a qualitative study examining personal experiences. J Ment Heal (2016) 25(3):260-6. doi: 10.3109/09638237.2016.1167856

162. Bryce S, Sloan E, Lee S, Ponsford J, Rossell S. Cognitive remediation in schizophrenia: a methodological appraisal of systematic reviews and meta-analyses. J Psychiatr Res (2016) 75:91-106. doi: 10.1016/j. jpsychires.2016.01.004

163. Brooks SJ, Burch KH, Maiorana SA, Cocolas E, Schioth HB, Nilsson EK, et al. Psychological intervention with working memory training increases basal ganglia volume: A VBM study of inpatient treatment for methamphetamine use. NeuroImage Clin (2016) 12:478-91. doi: 10.1016/j.nicl.2016.08.019

164. Brooks SJ, Wiemerslage L, Burch K, Maiorana S, Cocolas E, Schiöth H, et al. The impact of cognitive training in substance use disorder: the effect of working memory training on impulse control in methamphetamine users. Psychopharmacol (Berl) (2017) 234(12):1911-21. doi: 10.1007/ s00213-017-4597-6

165. LiX, Xiao YH, Zhao Q, Leung AWW, Cheung EFC, Chan RCK. The neuroplastic effect of working memory training in healthy volunteers and patients with schizophrenia: Implications for cognitive rehabilitation. Neuropsychologia (2015) 75:149-62. doi: 10.1016/j.neuropsychologia.2015.05.029

166. Ramsay IS, Macdonald AW. Brain correlates of cognitive remediation in schizophrenia: activation likelihood analysis shows preliminary evidence of neural target engagement. Schizophr Bull (2015) 41(6):1276-84. doi: $10.1093 / \mathrm{schbul} / \mathrm{sbv} 025$

167. Penadés R, Pujol N, Catalán R, Massana G, Rametti G, García-Rizo C, et al. Brain effects of cognitive remediation therapy in schizophrenia: a structural and functional neuroimaging study. Biol Psychiatry (2013) 73(10):1015-23. doi: 10.1016/j.biopsych.2013.01.017

168. Bechi M, Bosia M, Spangaro M, Buonocore M, Cocchi F, Pigoni A, et al. Combined social cognitive and neurocognitive rehabilitation strategies in schizophrenia: neuropsychological and psychopathological influences on theory of mind improvement. Psychol Med (2015) 45(15):3147-57. doi: $10.1017 /$ S0033291715001129

169. Lindenmayer JP, Khan A, McGurk SR, Kulsa MKC, Ljuri I, Ozog V, et al. Does social cognition training augment response to computer-assisted cognitive remediation for schizophrenia? Schizophr Res (2018) 201:180-6. doi: 10.1016/j.schres.2018.06.012

170. Campos C, Santos S, Gagen E, Machado S, Rocha S, Kurtz MM, et al. Neuroplastic changes following social cognition training in Schizophrenia: a systematic review. Neuropsychol Rev (2016) 26(3):310-28. doi: 10.1007/ s11065-016-9326-0

171. Lett TA, Voineskos AN, Kennedy JL, Levine B, Daskalakis ZJ. Treating working memory deficits in schizophrenia: A review of the neurobiology. Biol Psychiatry (2014) 75(5):361-70. doi: 10.1016/j.biopsych.2013.07.026

172. Prikken M, Konings MJ, Lei WU, Begemann MJH, Sommer IEC. The efficacy of computerized cognitive drill and practice training for patients with a schizophrenia-spectrum disorder: a meta-analysis. Schizophr Res (2018) 204:368-74. doi: 10.1016/j.schres.2018.07.034

173. United Nations Office on Drugs and Crime. Executive summary. Conclusion and policy implications of the world drug report 2017. World Drug Report 2017. United Nations publication, Sales No. E.17.XI.6. (2017), 36.

Conflict of Interest: The authors declare that the research was conducted in the absence of any commercial or financial relationships that could be construed as a potential conflict of interest.

The reviewer EL declared a shared affiliation, with no collaboration, with one of the authors EN to the handling editor.

Copyright (C) 2019 Guerin, Bonomo, Lawrence, Baune, Nestler, Rossell and Kim. This is an open-access article distributed under the terms of the Creative Commons Attribution License (CC BY). The use, distribution or reproduction in other forums is permitted, provided the original author(s) and the copyright owner(s) are credited and that the original publication in this journal is cited, in accordance with accepted academic practice. No use, distribution or reproduction is permitted which does not comply with these terms. 